\title{
MAFUTAGA SAMOA
}

By

\author{
Leilani Unasa
}

A thesis submitted to Victoria University of Wellington in fulfillment of the research requirements for the degree of Master of Arts in Creative Writing. 


\begin{abstract}
"MAFUTAGA SAMOA"
1 EXT. PEWTIFUL WHITE SAND, TROPICAL ISLAND BEACH - DAY.
\end{abstract}

Turquoise water laps the sandy white shore where coconut palms hang lazily over the sea.

The sound of a church choir singing a samoan hymn in the background.

A loud phone ring. The entire landscape shakes like crazy. What is this? An earthquake in paradise?

Pan out to reveal that the image is cell phone wallpaper. The phone rests on a church pew beside a bible and a samoan hymnoook. The ring tone is a tinny version of George McCrae's 'Rock Your Baby'.

The phone spills out a chorus before a hand frantically locates it and hits the off button.

[Press play to the real version of 'Rock Your Baby': intro soundtrack ]

Pull out to LAGI (61), a Samoan woman with grayish black hair and a face of stone, who turns around to glare at the cell phone offender. LAGI clutches a notebook and has a pen stuck behind her ear.

Back to TERRY (40) the offender in question, who smiles sheepishly? TERRY is devilishly handsome with a bit of dense mixed in.

EPELU (63), a slightly roundish, but nevertheless stately man, stands at the altar, delivering a prayer with closed eyes (Rock Your Baby is still all we hear at this point).

EPELU opens an eye and looks over at LAGI, taking notes in her notebook, and TERRY and subconsciously turns to address parishioners on the opposite side of the church.

The choir stands to sing another hymn.

MELESINA (36), heavily pregnant, pretty but not beautiful with jet-black hair and a widows peak, wobbles as she gets to her feet to sing with the choir. A woman beside her steadies her with a hand on the shoulder.

MELESINA smiles. 
MARCUS (15), awkward, lanky and in need of a tan, sits beside his father TERRY, slouching to disguise his true height and the fact that he's taller than TERRY.

MARCUS' gaze drifts off out the window. His fingers tapping out a frantic beat on the edge of the pew in front of him.

\section{CUT TO:}

2

INT. MANGERE METHODIST CHURCH TOILET - DAY

A toilet door. 'Rock Your Baby' lyrics '...now let the loving flow...real sweet and slow!' Bang...bang...bang. A man and woman are having sex inside. The woman giggles. The man shushes her. The woman giggles some more.

LAGI shuffles airline tickets in her battered and dog-eared notebook. Once finished, she closes the notebook with an air of finality ('Rock Your Baby' still playing).

The notebook is entitled 'TAFILI 2008' which is written in purple vivid.

LAGI gets up from her pew in the church and walks out.

EPELU, still delivering his sermon, follows her with his eyes. The rest of the church seems non-plussed.

EPELU nervously wipes his brow with a gingham handkerchief and coughs. 'Rock Your Baby' ends abruptly on EPELU's cough.

MELESINA looks over her shoulder at LAGI walking off into the church foyer.

\section{EXT. MANGERE METHODIST CHURCH GARDEN - DAY}

LAGI stands tucked away behind a collection of bushes at the back of the church. She stands underneath the church toilet windows . 
LAGI pulls out a manila envelope from her notebook, the contents of which are tobacco, a couple of filters and ZIGZAG papers.

LAGI winces in pain, and then quickly and efficiently rolls a smoke and pulls out a mini cigarette lighter from her bra cup.

Relief registers on her face almost immediately as LAGI lights up and takes a drag from the smoke.

Relaxing, LAGI takes time to soak in her surroundings and notices a rhythmic banging sound from the small open window shutter just above where she is standing.

LAGI leans in closer to the window, trying to make out what she is hearing.

A woman's low moaning. LAGI stands on tiptoes and peeps in the window.

LAGI

Who's in there?

LAGI face flashes with recognition.

\section{LAGI}

Bloody shits! This is a CHURCH for Christ's sake!

She quickly stubs out her smoke and dashes around to a side door into the church hall.

LAGI moves much quicker than her appearance belies. She is sprinting across the empty hall like a racehorse.

An African American man, ROBERT (30), hyper-tall, muscular basketball import, tucks in his shirt to his trousers as he comes bobbing out of the door.

ROBERT is followed by a subdued looking samoan woman with dyed blonde hair, ANNETTE (43).

ROBERT'S eyes lock on LAGI. A look of deep and intense fear crosses his face. ROBERT runs. LAGI stops.

LAGI

Robert? (beat) ROBERT! 
LAGI runs after ROBERT. The pair runs through the church hall and into the foyer. EPELU spots them from the altar.

EPELU

LAGI!!!

The congregation spins around. TERRY gets up and walks out to see what is happening. He starts jogging once he sees LAGI.

CUT TO:

5 INT. MANGERE METHODIST CHURCH FOYER - DAY

MELESINA waddles into the aisle trying to see what is going on. She lags behind the congregation that has now spilled into the foyer and out into the church car park.

6 EXT. MANGERE METHODIST CHURCH GARDEN - DAY

TERRY and ROBERT are having a punch-up, well, more of a wrestle.

It is fairly evenly matched up until the point at which ROBERT gains an advantage as TERRY slips on a pile of rotting leaves providing an opening for ROBERT to eye gouge TERRY.

ROBERT's wallet slips out of his pocket in the commotion.

MELESINA has caught up to the group that huddles around the fighting pair. She bursts through to see what is happening.

MELESINA

Robert? What's going on? Robert!

ROBERT

I'm sorry...

TERRY

FARRRRRKkkkkkk!!!!

MELESINA

Robert!! !

A shriek from the other side of the car park where LAGI is standing with ANNETTE and her fat, gout ridden husband ALENI (58). 
ALENI is clinging on to ANNETTE who is trying to swat him away •

\section{ALEN I}

Come on, baby...darling!! Don't go, don't go!!! You can't leave me!

\section{ANNETTE}

Get off me! I hate you - you fat, lazy shit smelling pig!

ROBERT takes this chance to run. He ducks into a car, stalls the engine, gets it going and bunny hops down the driveway.

ANNETTE kicks ALENI in his swollen gout ankle, runs after the car and bangs on the door for ROBERT to let her in.

After ROBERT bunny hops the car three times, he stops, leans over and unlocks the door.

ANNETTE is in like a shot and the car zooms off down the road.

MELESINA is standing stunned with her mouth hanging open.

TERRY nurses an eye that is quickly turning purple. Shaking his head all the while and trying to resist the urge to laugh.

MARCUS stands in the church doorway madly texting but with eyes glued to the action.

MARCUS

Random!

EPELU walks up behind MARCUS.

EPELU

Very...

CREDITS- MAFUTAGA SAMOA

7 EXT. LEFAGA LAGOON, SAMOA - DAY

A ragged, skin and bones dog cocks its leg and pisses onto a stony beach. The stream of hot urine makes its way to meet the tide. The water is a muddy green. 
The dog skits back up the beach and up to the steps of a large, white concrete church hall and slips in an open door and runs into...

...LINE (60) who instinctively flicks the dog away with a bunch of papers she holds in her hand. LINE is small and petite and moves like fire.

TUI (63), wiry and muscular with jet black hair and a widows peak, stands gluing life-sized head and shoulder photographs of people onto a huge family tree that spans the walls of the church hall.

Pieces of thickly twirled black crêpe paper make the branches of the family tree.

MAKO (7), a skinny, toothy boy, stands beside TUI holding a glue bottle and chomping down on a piece of sugarcane.

LINE comes along behind TUI inspecting each photograph. Her eagle eyes scan across photographs of TERRY, MARCUS, MELESINA.

LINE's eyes come to a photograph of LAGI. One crepe paper branch represents both LINE and LAGI whose photos are jammed almost on top of each other.

LINE rips LAGI off the family tree and screws the photograph up violently, and thrusts it at MAKO.

\section{LINE}

Don't need that.

TUI

You can't change the family tree.

\section{LINE}

Really? She's not going to be here anyway. Nobody will notice. Look, you've ripped my photo now- I'll have to get another one.

LINE gives the papers from her hand to MAKO.

\section{LINE}

Take these programmes to Tusitala.

Make sure he isn't wearing his

glasses, I don't want him making

any last minute changes. 
LINE marches off into the hall kitchen.

\section{LINE}

Hey! You girls, get a move on!

Work doesn't get done by itself.

TUI

Everyone knows you've got a twin

Line...

MAKO skips out of the hall with his hands full. As he does, the screwed up photo of LAGI drops on the hall steps and the sea breeze blows it gently into a Ti bush.

CUT TO:

TUSITALA (83), a wiry elderly man with a frangipani flower tucked behind his ear, steps inside the hall. He bends down to pick up the screwed up picture from the Ti bush.

Unrolling it, TUSITALA chuckles and smoothes it out.

CUT TO:

8 INT. LEFAGA METHODIST CHURCH HALL, SAMOA - DAY

TUSITALA licks the back of LAGI's photo and sticks it back up on the wall right next to LINE.

LINE walks up stealthily behind TUSITALA looking very perturbed.

Without turning around TUSITALA addresses LINE.

TUSITALA

You two were always so

alike...always fighting like hungry

dogs...but always so alike.

LINE

Mako's looking for you Tusitala. 
9 INT. LAGI'S KITCHEN, MANGERE - DAY

MELESINA is alone, weeping whilst sitting at the kitchen table. A plate of Cook Island doughnuts sits in front of her. MELESINA picks up a doughnut and stuffs as much of it into her mouth as possible.

Translucent snot runs down MELESINA's nose and onto the edge of the doughnut as she eats it.

The muffled sounds of LAGI and EPELU arguing in the room next door.

10 INT. LAGI'S BEDROOM - DAY

EPELU sits on the edge of the king sized bed folding items of clothing as LAGI throws them on the bed from a large scotch dresser.

LAGI starts packing a large stack of towels into a huge plastic red, white and blue stripy bag.

EPELU

She doesn't want to go Lagi. Leave it alone!

LAGI

Don't be silly. She'll be fine in

the morning. She needs to get over

that Robert is what she needs.

EPELU

I don't know why you've decided to go to the reunion all of a sudden.

CUT TO:

11 FLASHBACK INT. DOCTORS SURGERY, PAPATOETOE - DAY

LAGI sits in the Doctors surgery waiting room flicking through a magazine.

The doctor walks a patient back out into the waiting room. The patient is an older woman who has lost her hair from chemotherapy treatment. 
LAGI is visibly affected by seeing the woman. Shocked, she gets up and walks out of the surgery.

\section{CUT TO:}

LAGI

Well...I just...well, family of course! I'm allowed to go to my own family reunion - aren't I? And...to support Terry and Marcus. And Mele. It'll be lovely. The four of us. That boy needs to see where his roots are. He's already been through half of Asia for goodness sake!

EPELU

Did you even bother to ask Mele if she wants to go? Or any of them?

13 INT. LAGI'S KITCHEN TABLE - DAY

LUCY (40), a tall blonde reminiscent of Rachael Hunter, bursts through the backdoor. LUCY sees MELESINA and immediately drops her handbag on the floor and hugs her.

LUCY

Hey...it's alright...it's alright...

LAGI comes into the kitchen with a half full bottle of whiskey •

\section{LAGI}

I think we all need one of these.

Oh, hello Lucy.

LUCY

Hello Lagi.

\section{LAGI}

Word travels fast around here doesn't it? 
MELESINA
I can't just leave Robert

LAGI

I don't think that's the problem

my dear. Robert's left you. Oh,

yes, that's right. Here.

LAGI reaches down beside the table and pulls ROBERT's wallet out of her handbag.

MELESINA stares at it blankly.

LAGI

Dropped it in the car park. I

suppose you've heard from him? You

can arrange to return it then?

LAGI skulls back her whiskey and goes to grab MELESINA's glass. MELESINA takes the glass instead for herself, looks into it, takes a whiff of alcohol and vomits all over the table.

\section{Towel!}

\section{LAGI}

LAGI starts rubbing MELESINA's back. In the lounge, EPELU jumps up and opens the towel cupboard in the hallway.

Rummaging around for the last clean towel left in the empty cupboard, EPELU stumbles across a bundle of letters addressed to LAGI.

All of the letters are from the hospital.

14 EXT. BEACH ROAD, SAMOA - MID MORNING

LAFAELE (37), a huge Samoan man, as tall as he is wide is hunched into the driver's seat of a crappy white Toyota Sedan.

A set of metallic beads and a rosary hang from the rearview mirror. A small jade Buddha sits blue tacked to the dashboard and mini American flags poke out of the air-conditioning vents. 
SA'ANE (40), a striking Samoan woman and Lafaele's sister, sits in the passenger seat behind LAFAELE. SA'ANE wears a padded neck brace.

The Toyota zooms past villages lined with faleo'o (Samoan fale), village kiosks, dusty sea, women with fish hanging on lines for sale, people waiting for buses, pigs, chickens, horses.

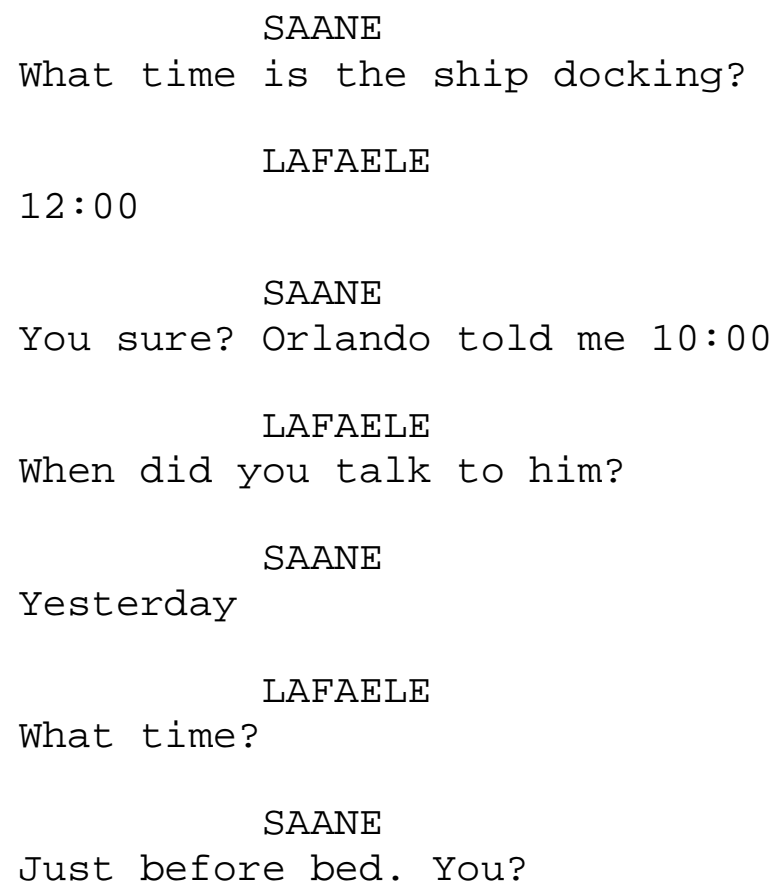

SAANE's cell phone rings. It sits on the backseat and slips off onto the floor as it vibrates. SAANE reaches to get it but can't as she is restricted by her neck brace.

\section{SAANE}

Pull over! It'll be Customs

wanting the clearance number or they'll send the container back! 
Wait.

\section{LAFAELE}

LAFAELE twists himself and stoops to pick up the phone on the floor behind him while trying to retain control of the steering wheel.

\section{SAANE \\ Stop it! You're too fat!}

LAFAELE fails to reach the phone and the car veers onto the other side of the road.

A speeding Samoan bus approaches from the opposite direction. The phone is still ringing.

LAFAELE swerves back onto the right side of the road only to find that he has overcorrected and is now on track to hit a pig and her piglets on the grass bank beside the road.

Rather than hit the pig, LAFAELE swerves onto a flat grassy strip. Rocks in the grass slow the car down and it comes to a halt just outside of a huge grave monument in front of a green and pink striped fale.

A middle-aged man is sleeping in the shade on the grave. He snores loudly as the bonnet of the car nudges his foot gently.

LAFAELE and SAANE sit, semi-dazed. SAANE snaps out of it and slaps LAFAELE around the back of the head.

SAANE

Next time I'm driving you arse!

The phone starts ringing. SAANE answers in a dramatically altered sickly sweet voice.

SAANE

Talofa? Yes, we will be paying the

fee today. A delay? But it's

already been delayed a month! It's

on Nukunonu? In Tokelau?? But

we're having one hundred people

arriving tomorrow and they need a

toilet! 
15 EXT. LEFAGA VILLAGE MALAE - DAY

The malae - an open, flat, grassed area the size of a cricket pitch.

In the centre of the malae, a torn volleyball net waves softly in the sea breeze. Beside the net are two young men attempting to unfold a large white banner. They keep twisting it instead of straightening it and laughing at each other.

A couple of chickens root around in the dirt next to the men.

\section{EXT. LAGI'S HOUSE - AFTERNOON}

TERRY is loading heavy suitcases into the back of a large $4 \mathrm{WD}$.

MARCUS makes a token effort to help by bringing out a small brown carryon bag from inside of the house.

A late model silver Mercedes pulls up into the driveway.

ARNOLD (47), a well suited Chinese man wearing expensive sunglasses, jumps out of the drivers seat followed by LUCY from the passenger seat.

\section{ARNOLD}

There's no bloody reason for you

to go Lucy.

LUCY

I already told you why Arnold. I'm

not going to talk about it again.

It's only for a week.

ARNOLD

Well, I'm coming with you then.

LUCY

No you're not

ARNOLD

Yes I am

LUCY

You bloody aren't Arnold! 
TERRY

What's this?

MARCUS

Mum's coming.

TERRY

What?

ARNOLD

Don't you even think about, you

know... I know what you're like Terry

ARNOLD eyes TERRY and then eyes LUCY while she begins to pack a large pink vinyl crocodile print suitcase into the 4WD.

LUCY

Don't be ridiculous Arnold!

TERRY

What, what's going on?

MARCUS

Mum's coming.

TERRY

What?

ARNOLD

Melesina can look after herself

Lucy. Your aunty can look after

herself aye Marcus?

LUCY

Stop being so selfish! It's only a

week. Get over it. Her husbands

just run off with the church bike, she's pregnant, her hormones are totally out of control and she's going to Samoa for the first time with the 'Iron Maiden' in there!

You know that bastard Robert

hasn't even called her? What a prick!

TERRY

What's going on? 


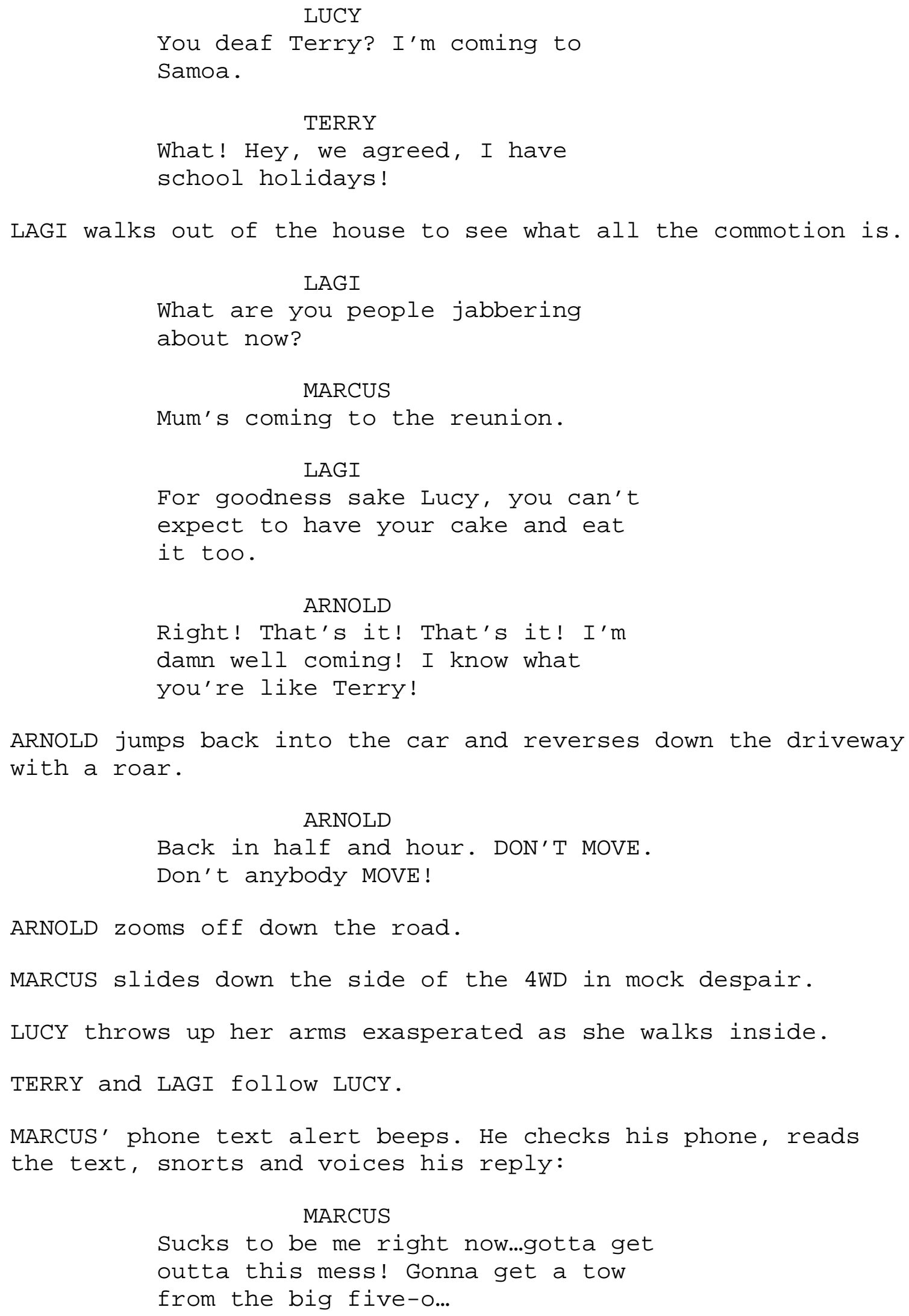

\section{ARNOLD}

Back in half and hour. DON'T MOVE. Don't anybody MOVE!

ARNOLD zooms off down the road.

MARCUS slides down the side of the 4WD in mock despair. LUCY throws up her arms exasperated as she walks inside. TERRY and LAGI follow LUCY.

MARCUS' phone text alert beeps. He checks his phone, reads the text, snorts and voices his reply:

MARCUS

Sucks to be me right now...gotta get outta this mess! Gonna get a tow from the big five-o... 
17 INT. LAGI'S KITCHEN - AFTERNOON

EPELU makes a cup of tea at the kitchen bench. He carries it through to MELESINA who is stretched out on a lazy boy in the lounge.

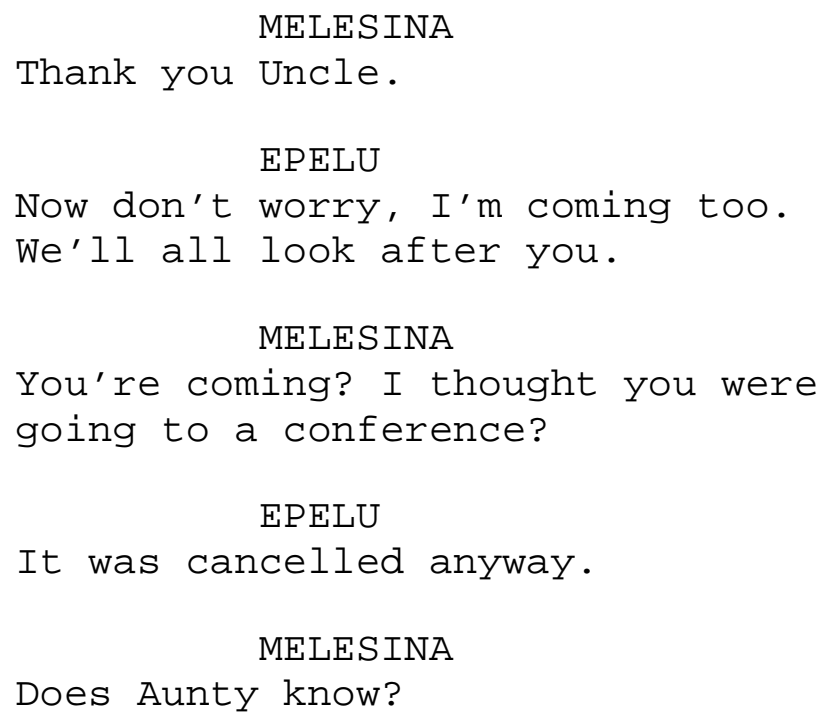

\section{EXT. - TRAVELLING - AIRPORT SHUTTLE, AUCKLAND}

TERRY sits in the front next to the driver who is a middleaged Cambodian man with a broad Kiwi accent.

MELESINA is staring blankly out the window and clutching her belly.

LUCY is occupied with rearranging the contents of her very large red patent leather handbag.

ARNOLD sits beside LUCY flicking through emails on his palmpilot.

MARCUS is plugged into an IPod.

EPELU and LAGI sit in the back seat.

DRIVER

Nice family trip planned then aye?

TERRY

Yeah. Family reunion. Should be a cracker. 
DRIVER

Good on yah. Got one of those

planned myself for Christmas time.

Just hoping we don't all strangle

each other by then! Haha!

ARNOLD

Remind me to check out the new

pricing for these in duty-free.

Marcus? (beat) Marcus? Thought we

might pick up the new Nintendo Wii

while we're at it.

MARCUS unplugs one ear.

\section{MARCUS}

Oh yeah. Choice.

TERRY hears this and shuffles uncomfortably in the front seat.

\section{LAGI}

This was supposed to be just the

FOUR of us. You really didn't need

to be here at all, or these

hangers-on.

EPELU

What are those letters about?

LAGI

What letters?

\section{EPELU}

You know what I'm talking about.

LAGI

Did you read my mail?

EPELU

Would I do that Lagi?

LAGI

Just some study at the medical

school thing. You know, like the

one I did last year...

EPELU

Really? 


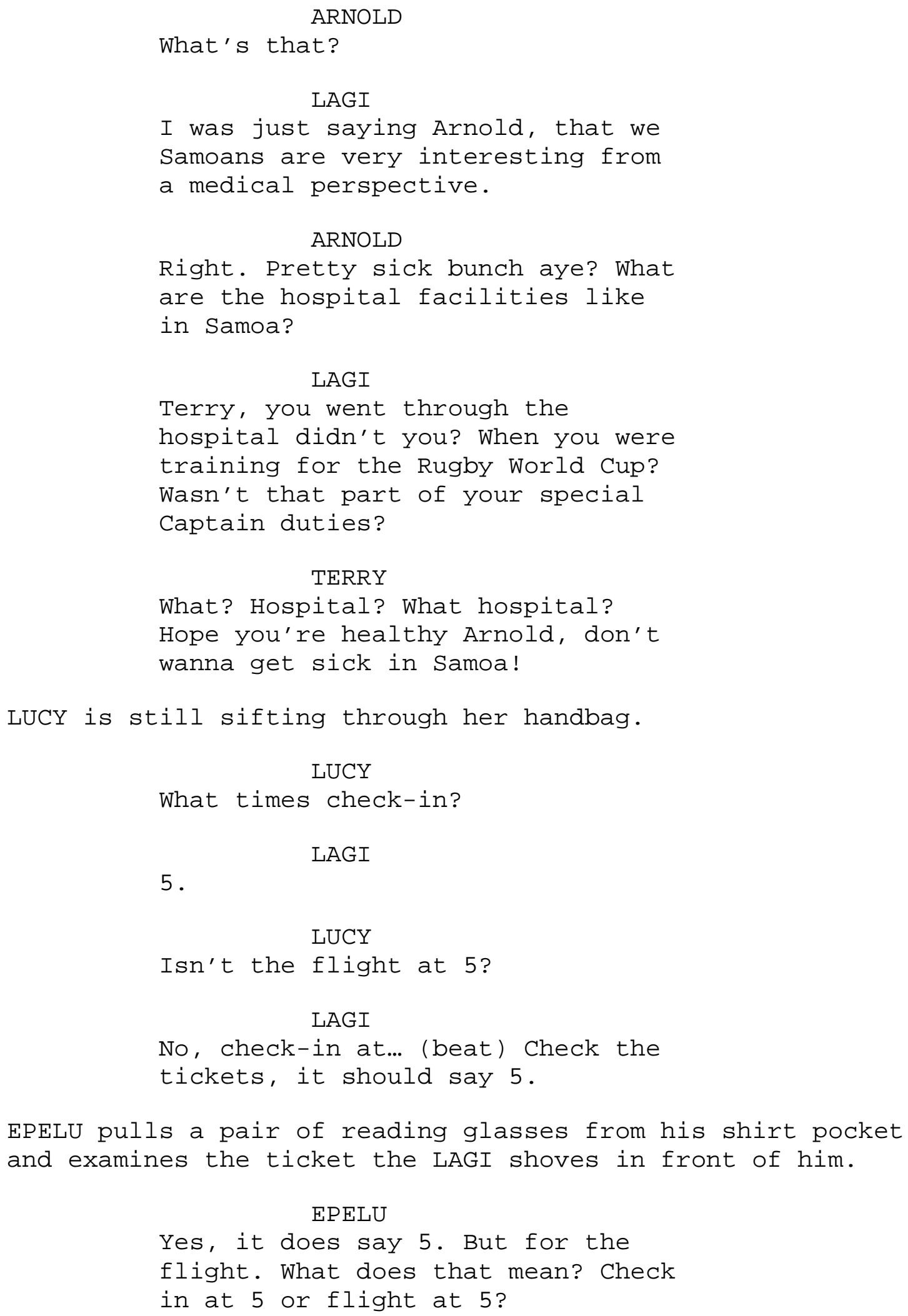

EPELU pulls a pair of reading glasses from his shirt pocket and examines the ticket the LAGI shoves in front of him.

EPELU

Yes, it does say 5. But for the

flight. What does that mean? Check

in at 5 or flight at 5? 


\section{TERRY}

It means the flights at 5 ! Shit,

its 4 now! We should've checked in

at 3 !!

CUT TO:

19 EXT. AUCKLAND INTERNATIONAL AIRPORT - DAY

The wheel of the taxi van hits the edge of the curb with a screech.

A pair of legs jumps out and grabs a row of baggage trolleys from the outside of the terminal.

More legs follow in a frantic fashion.

Bags are thrown onto the trolleys and wheeled with speed into the terminal.

20 INT. AIR NEW ZEALAND INTERNATIONAL CHECK-IN COUNTER DAY

A stern looking male airline attendant looks at the ticket in front of him and then at the group of Tafili's eagerly awaiting his verdict.

\section{ATTENDANT}

No.

LAGI

What?

\section{ATTENDANT}

No. It's too late. You should have been checked in by 3 .

EPELU

It's only quarter past four now.

Plenty of time.

LAGI

All you need to do is press some

buttons, print the boarding passes

and get us on! If you get to it 


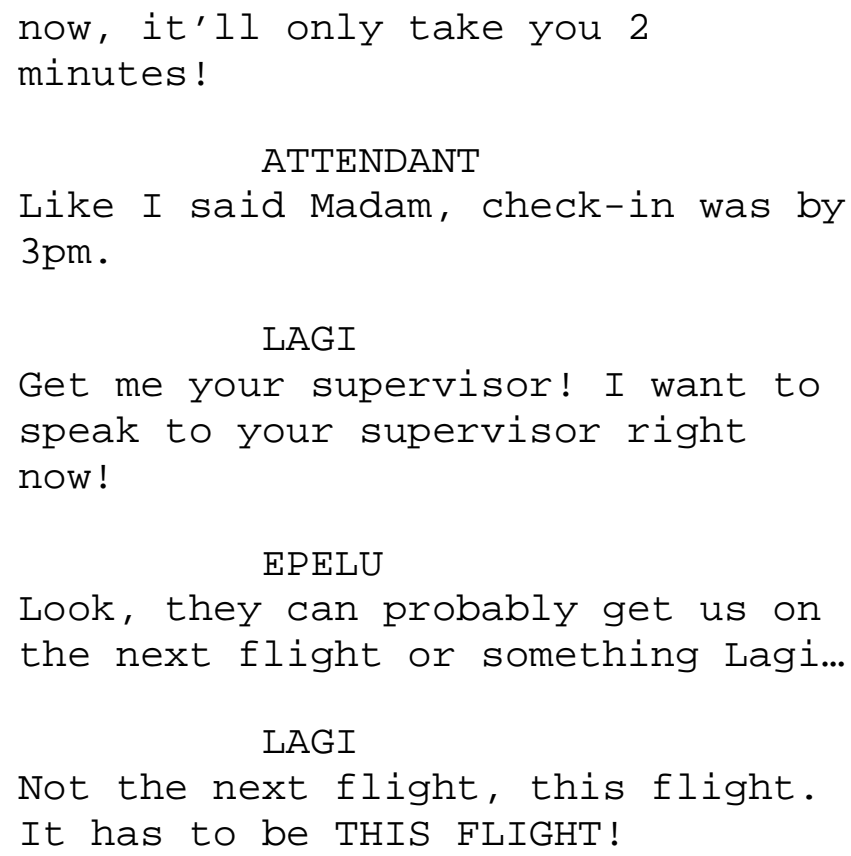

The attendant screws his mouth up and forcefully dials a phone number.

\section{ATTENDANT}

Yes, Linda, can you come down. I have a 'situation'. Flight 432 . (beat) Thank you. Please wait to the side. Thank you. NEXT!

CUT TO:

21 INT. AIR NEW ZEALAND TERMINAL SALES COUNTER - DAY

The group huddles around the small sales counter with their mountain of baggage.

TERRY and MARCUS sit to one side on some chairs.

\section{TERRY}

Well son, if we can't get on a flight, maybe we can just stay here and go for a cruise down the line.

MARCUS

Yeah? 
LINDA (33), a slim Samoan airhostess, walks towards the group from an office. She spots TERRY.

$$
\text { LINDA }
$$

Oh my gosh! Terry, is that you?

TERRY swivels around to see LINDA.

\section{TERRY}

Ah yeah! Good to see you...

LINDA

Linda! Is this your group?

TERRY

Yeah. Bit of a mix up with the boarding time.

\section{LINDA}

Oh, don't worry about it, Mark was just have a power trip. You know, palagis... There's plenty of time to load. Where's the tickets?

CUT TO:

22 INT. AIR NEW ZEALAND BOARDING COUNTER - DAY

LINDA hands over the pile of travel documents to LAGI.

\section{LINDA}

Right. All done. Now, you'd better jog through the terminal to the gate. They know you're coming but you've got $20 \mathrm{mins}$ to be there. So no stopping for duty free anyone, unless it's to get me some Vodka okay? Uhm, Terry, forgot this.

LINDA slips TERRY her business card with a handwritten mobile phone number on it and two kisses.

LAGI hands out the travel documents, calling out the owners one by one.

\section{LAGI}

Arnold...Lucy...Marcus...Terry, you've got yours...Melesina...where's 


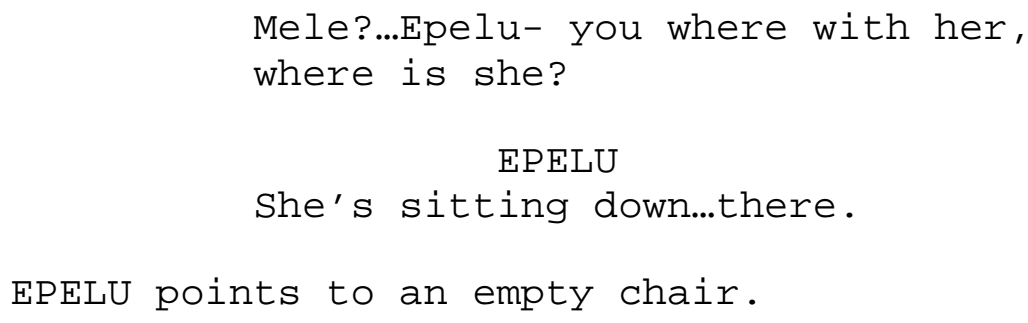

MELESINA's cell phone beeps through a text message from ROBERT. She studies ROBERT's name flashing on the phone and then switches the phone off.

\section{MELESINA}

Give me these, and the Dior's.

MELESINA pulls out Robert's wallet from her bag. She is already totting three other duty free bags.

\section{CUT TO:}

24 INT. AIRPORT WOMEN'S TOILET - DAY

MELESINA sits in a toilet cubicle surrounded by her shopping. It is a tight squeeze. 
MELESINA pulls out her cell phone - scrolling through a long list of text messages all from ROBERT.

MELESINA pulls the phone SIM card out from the back of the phone and drops it down the chute of the feminine hygiene products disposal.

MELESINA smiles to herself, pulls a pen out of her handbag and tags on the bathroom door:

'www. robertghana.sucks.dick. lots'

\section{INT. AIRPORT DEPARTURES LOUNGE DAY}

MELESINA comes out of the toilet wearing her new sunglasses and bumps into LUCY.

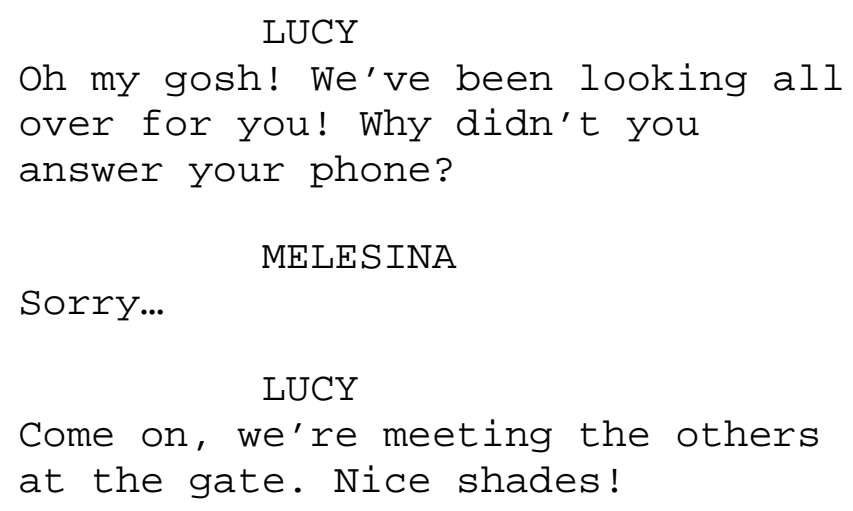

MARCUS is milling around the same shop that MELESINA was in earlier. His eyes shift around looking out for the shop assistant. He is wired.

Said shop assistant is chatting animatedly on the phone with her back turned.

The tray of expensive sunglasses is still out on the counter. MARCUS sidles up to the counter and swipes a pair of diamante encrusted Chanel frames. He puts these up his jersey in a fairly obvious fashion. 
The shop assistant finally notices him, gives a friendly wave and hangs up the phone.

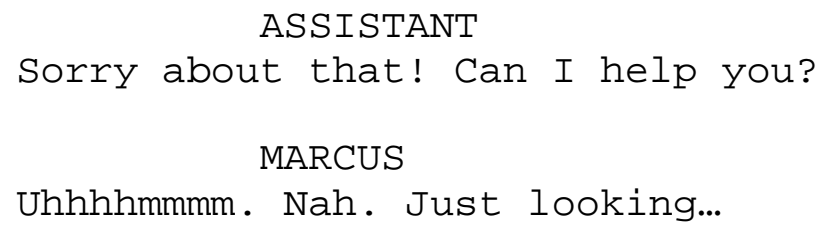

The shop assistant takes the tray and puts it back in the locked cabinet, not noticing the missing sunglasses. The assistant goes to change the $C D$ that has begun to skip.

MARCUS waits until she is looking again and, very obviously, takes a another pair of sunglasses and this time puts these on his head and goes to walk out.

However, at the same time, a young Samoan man who is handcuffed sprints through the terminal with a pair of security guards and an immigration officer puffing after him. The shop assistant runs out to have a look at the action.

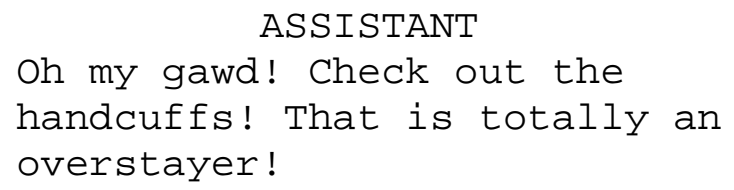

MARCUS, dejected, chucks both pairs of sunglasses on top of one of the counters and walks out of the shop.

LAGI snaps him up as he steps back out into the terminal. The rest of the Tafili party follows.

\section{LAGI}

There you are! Get going! We've got 10 minutes to get through the gates. I'm going to stick myself to you like glue young man! Hurry, hurry!

MARCUS sighs and rolls his eyes. 


\section{INT. AIRPLANE CABIN - NIGHT}

MARCUS sits in between LAGI and MELESINA hunched in airplane seating. MELESINA dozes with her head resting on MARCUS' shoulder.

LAGI sits upright rubbing cream from a white plastic tube into her hands. Her notebook sits on the tray table along with a cup of tea and an opened packet of Fruit Bursts.

TERRY, LUCY and ARNOLD occupy the row adjacent. TERRY occupies the aisle seat and is flirting with the airhostess as she stands shuffling pretend luggage around in the overhead locker.

TERRY's tray table has a can of beer, a bourbon and coke, and one glass full of ice.

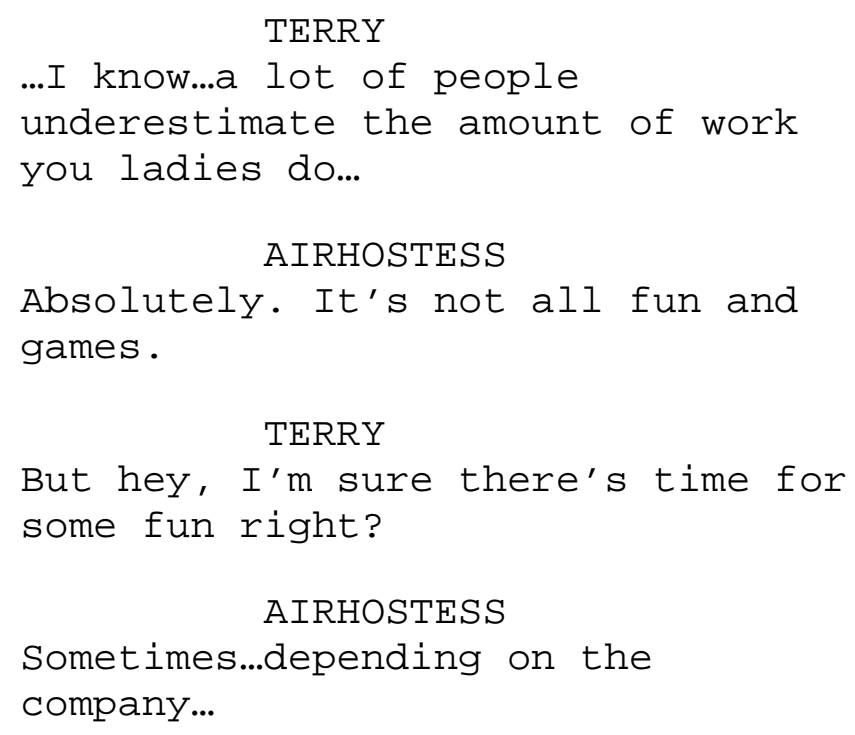

ARNOLD looks at TERRY sideways and taps through emails on a palm pilot.

Oblivious to this, LUCY sits in the window seat listening to an Ipod and reading from a thick historical romance novel.

CUT TO:

\section{INT. AIRPLANE CABIN - NIGHT}

EPELU sits directly behind LAGI and next to a young mother and bawling baby beside him. 
EPELU is making honorable attempts at distracting the baby. He succeeds and the baby gives him a wide gummy smile and then rips his glasses off his head ruthlessly.

EPELU howls with laughter at this and shakes the baby's chubby hand. The baby coos and laughs too.

29 INT. LEFAGA VILLAGE METHODIST CHURCH HALL, SAMOA - NIGHT

Moths flit around the light of the church. Below them is a hive of activity.

LINE is in command of a small army of female workers who are setting up and decorating the hall.

So far the hall is set up lecture style with approx 20 trestle tables ready to receive people. Plates and cutlery are stacked up at the end of each table. The walls are decorated with yellow and red streamers.

There is a large banner at the front of the hall that says 'Mafutaga 2008 - A'iga Tafili'. Underneath the words is a hand-painted picture that looks like a mermaid sitting on top of a huge pumpkin. There is a speech bubble from the mermaid that says 'Afio Mai, Susu Mai. Welcome all Tafili family'.

A brightly painted van pulls up outside the Methodist Church Hall.

The van driver, seen from behind, reaches into the glove compartment and pulls out a bottle of lavender coloured aftershave.

The driver, ORLANDO, (38) a sifty man aspiring to be Elvis/ James Dean/ Clint Eastwood sprays aftershave liberally over himself before smoothing his hair down with spit. 
CUT TO:

31

INT. LEFAGA METHODIST CHURCH HALL - NIGHT

ORLANDO waltzes into the hall. LINE spots him immediately and makes her way over to him.

\section{LINE}

Hello darling.

LINE gives ORLANDO a big kiss on the cheek and a warm hug.

ORLANDO

Van is ready outside.

\section{LINE}

Thank you darling. I know you're

busy, thank you. Take Lafaele with

you. Plane arrives at $10 \mathrm{pm}$.

Talia! No, no, no, diamond, not

square! Get your head on the job!

Don't be as brainless as you look!

A magnificent whale shark surfaces the water for a split second before it dives back down into the lagoon.

TUI sits in his canoe just on the edge of the reef. He is night fishing and his canoe is illuminated by torchlight. There are a few canoes off in the distance but other than that he is alone.

TUI is staring at a red plastic container with a lid on it that sits at the opposite end of the canoe.

TUI opens it and pulls out a plastic bag.

He opens the bag and takes out three photos. One photo shows MELESINA sitting with ROBERT on a couch smiling with her head rested against $R O B E R T^{\prime}$ 's shoulder.

The other photo shows MELESINA and a group of young girls in netball uniforms. 
The last photo is a faded black and white photo of a solemn young Samoan woman carrying a small baby wrapped in blankets and holding the hand of a young boy.

TUI studies each photo carefully before placing them back in the envelope and plastic bag and then back in the red container.

TUI seals the container tightly.

Unseen by TUI, the whale shark glides gracefully under the canoe sending a rogue wave that topples the container over into the water.

\section{EXT. TRAVELLING - NIGHT}

ORLANDO and LAFAELE are sitting in the bus.

ORLANDO drives, LAFAELE attempts to comb his wayward afro hair whilst the van jumps about over potholes and the like.

'Ao ma le Po' by the RSA Band plays on the radio.

A smoke hangs out of the side of ORLANDO's mouth. ORLANDO turns the radio off.

$$
\text { ORLANDO }
$$

So.

LAFAELE doesn't respond and keeps combing his hair. ORLANDO slaps the comb away from LAFAELE. It lands on the floor.

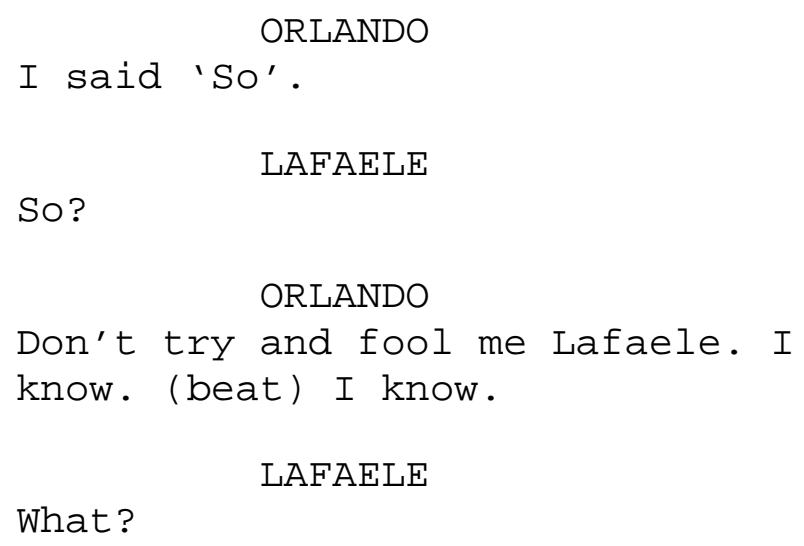




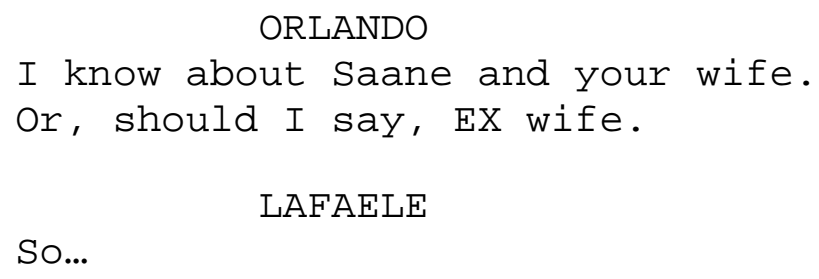

LAFAELE nervously wipes sweat from his upper lip.

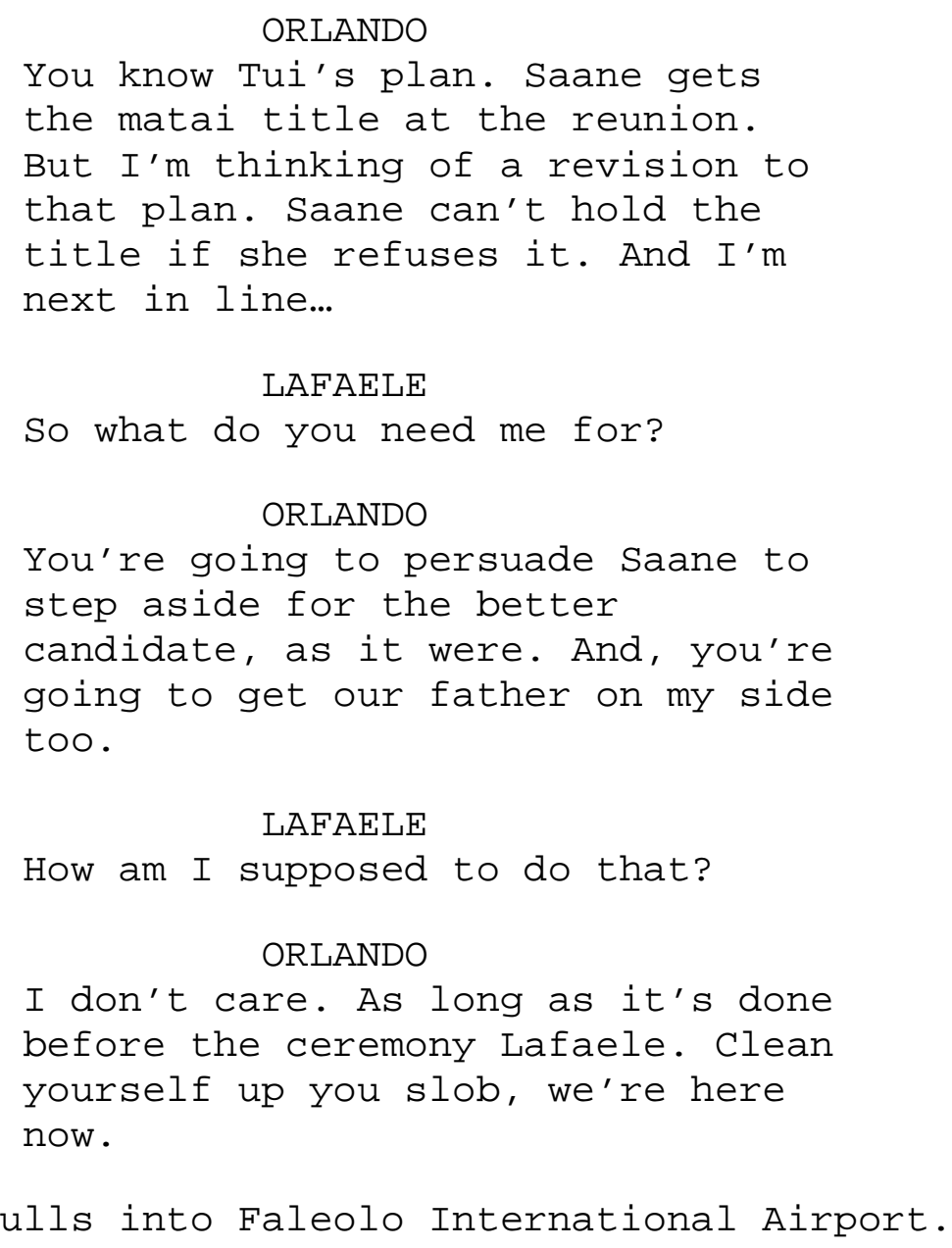

34 INT. AIRPLANE CABIN - NIGHT

A large soft toy tiger lies next to a little girl who has fallen asleep in her seat. Her mother chews gum and looks out the window.

MELESINA is snoring in her seat with her mouth gaping open. 
EPELU holds the now sleeping baby whilst its mother searches around in a handbag.

CUT TO:

35 INT. AIRPLANE TOILET - NIGHT

LAGI sits on the toilet spraying Rescue Remedy under her tongue and breathing deeply through her nose. No noticeable effect from the Rescue Remedy.

LAGI pulls out a container of pills from her handbag. She swallows down two quickly.

LAGI sits sit for a few seconds, looking across at herself in the toilet mirror.

\section{CAPTAIN}

(O.S) Good evening folks. We're

about to begin our descent into

Apia. We've had a pretty good run

and should be outside the terminal

in about ten minutes.

With much urgency, LAGI rips back into the Rescue Remedy, madly spraying. Not enough comes out.

LAGI rips the top off the Rescue Remedy and swallows the entire contents of the bottle.

36 INT. AIRPLANE CABIN - NIGHT

Close up on a blue screen at the front of the plane cabin. It shows New Zealand and Samoa and there is a red line drawn between the two. The plane rests on the dot which says 'Apia'.

The seat belt signal is switched off. Synchronised clicking of seatbelts as passengers move to get their belongings and make their way from the plane.

CUT TO: 
TERRY stands at the airplane door with his arms wide open. He takes a deep breath in, savouring the richness of the Samoan air. Mostly, this is because he is half-pissed. MARCUS follows TERRY down the steep airplane steps and onto the tarmac. MARCUS has already started to sweat in the heat.

LUCY and ARNOLD follow, bickering as they go.

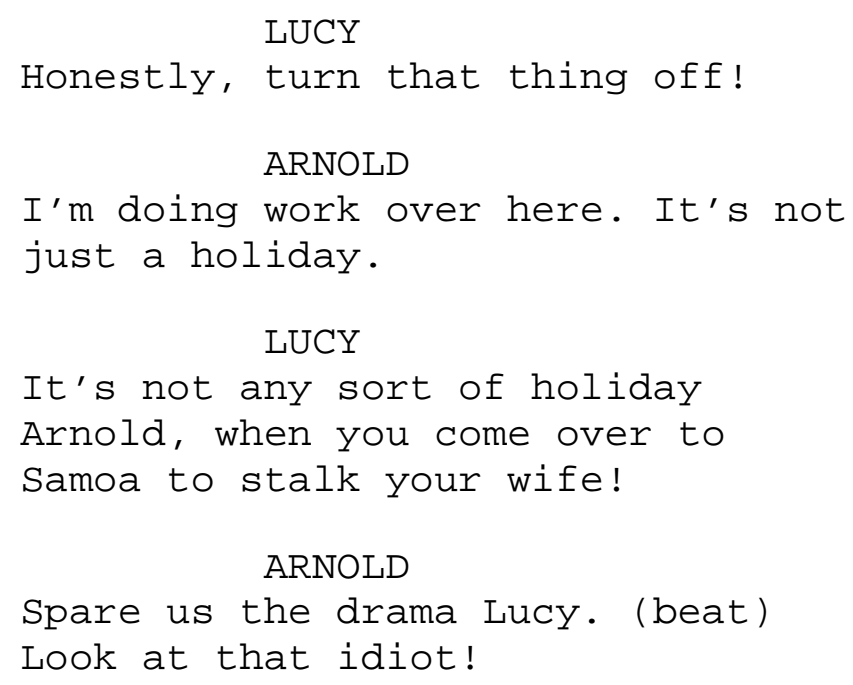

TERRY stops to shake the hands of airport staff that line the entrance to the airport. Some of the women giggle. The men pat him on the back. They've seen this behaviour before.

MELESINA peers her head out of the plane door tentatively. EPELU guides her out and down the steps.

EPELU

Careful Sina. These are very steep.

MELESINA

Oh my gosh! It's like walking into

an oven! Where's Aunty?

EPELU

The Ladies.

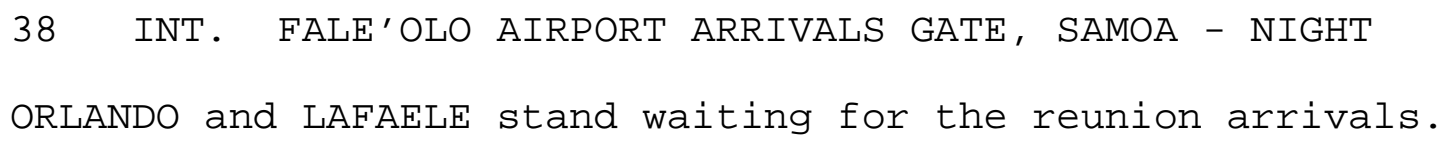


ORLANDO spots TERRY and MARCUS and waves out. TERRY jogs over and gives ORLANDO and LAFAELE each a bear hug.

MARCUS brings up the rear pushing a trolley laden with luggage.

MARCUS is already sweating profusely with sweat patches forming under his arms.

TERRY

Marcus! Marcus, come here son.

This is Orlando, and this is

Lafaele. Our cuzzies. I stayed at

Lafaele's when I came over for the

rugby tour.

ORLANDO

Talofa Marcus. He's handsome like you Terry!

ORLANDO shakes MARCUS' hand and squeezes MARCUS' bicep.

ORLANDO

And your muscles!

TERRY

Nah, they're his mothers.

TERRY chuckles and pulls out a carton of cigarettes from a duty free bag and stuffs it under ORLANDO's arm.

ORLANDO

Oi? I'a. Thank you!

ORLANDO holds up the carton, lightly touches his head with it and then points it back towards TERRY- like taking ones hat off to someone.

LAFAELE

It's hot aye Marcus?

MARCUS

Oh. Yeah.

LAFAELE

You're taller than your dad now aye. 
TERRY

Been taller than me since he was

13 !

ORLANDO

Oh well, as long as you're tall

where it counts aye Terry!

TERRY

You know me!

The two men laugh heartily. MARCUS shuffles and looks down at his feet. LAFAELE looks a little uncomfortable.

LUCY and ARNOLD catch them up. ORLANDO's eyes nearly fall out when he sees them and he whispers under his breath.

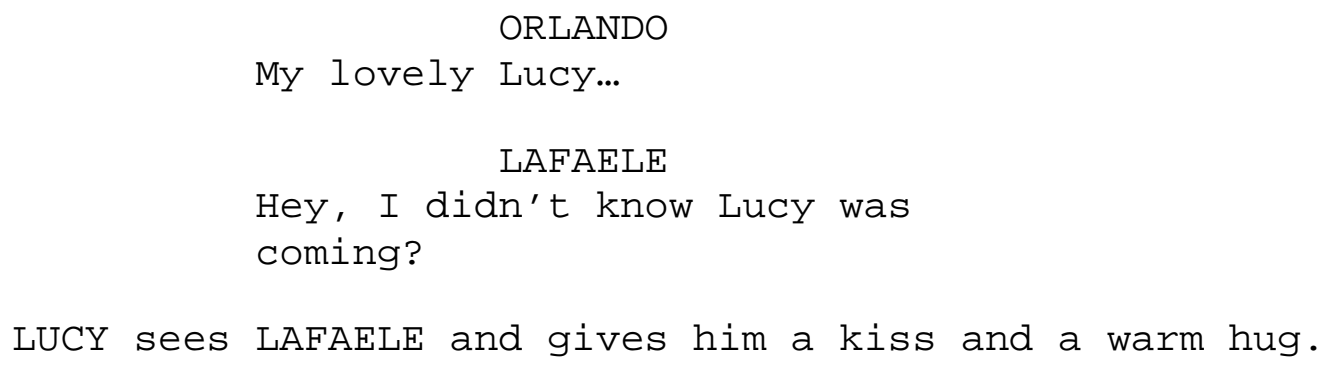

No kiss for ORLANDO.

ARNOLD introduces himself, shaking ORLANDO and LAFAELE's hands firmly and businesslike.

ARNOLD

Arnold. Civil engineering. Pleased

to meet you. 
Malo Arnold.

ORLANDO/ LAFAELE

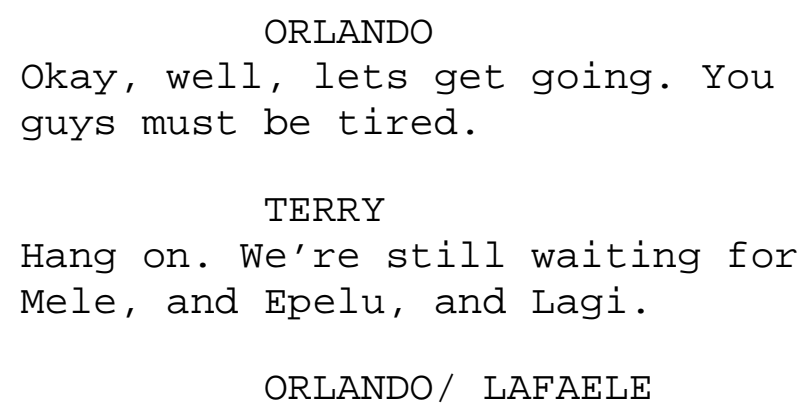

LAFAELE and ORLANDO huddle underneath the small curtain of an automatic photo booth, madly whispering. The curtain is so small it only covers both of their heads with the rest of them exposed.

The Tafili travelers stand a few metres away looking in the opposite direction.

\section{LAFAELE}

She's gonna go crazy! We need to warn her! Did you know Lagi was coming?

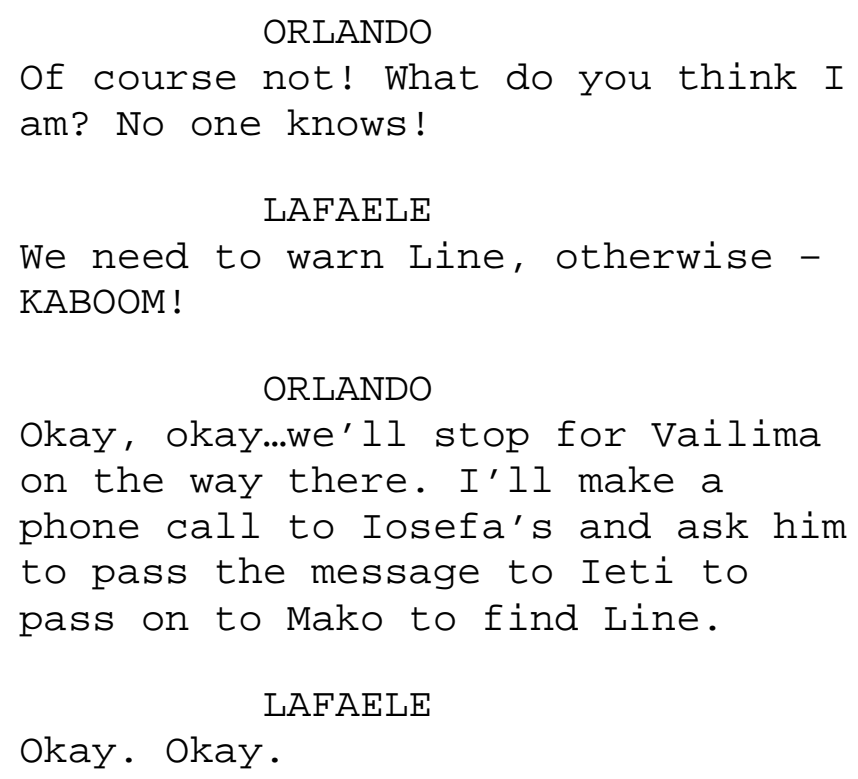


A camera flashes and catches LAFAELE mid sentence.

CUT TO:

A photograph of ORLANDO blinking and LAFAELE with his hand through his afro and mouth open.

40 EXT. TRAVELLING, BEACH ROAD - NIGHT

MARCUS sticks his head out the van window as it speeds down Beach Road. His eyes start to water from the wind and he pulls himself back inside the van.

TERRY sits in the front with ORLANDO. MARCUS sits directly behind him. LAGI sits in the middle of the van next to MELESINA.

EPELU, LUCY, LAFAELE and ARNOLD are spread throughout.

The van pulls up to a small village kiosk with a huge Vailima sign. ORLANDO jumps out and goes into the kiosk.

LAFAELE

We didn't know you were coming

Lagi?

LAGI

Last minute decision.

LAFAELE

Line will be very pleased.

LAGI

$I^{\prime} m$ sure.

MARCUS

How many people are gonna be there

Dad?

TERRY

Not sure.

LAFAELE

About one hundred? Mostly coming

on the early morning flight

tomorrow. 


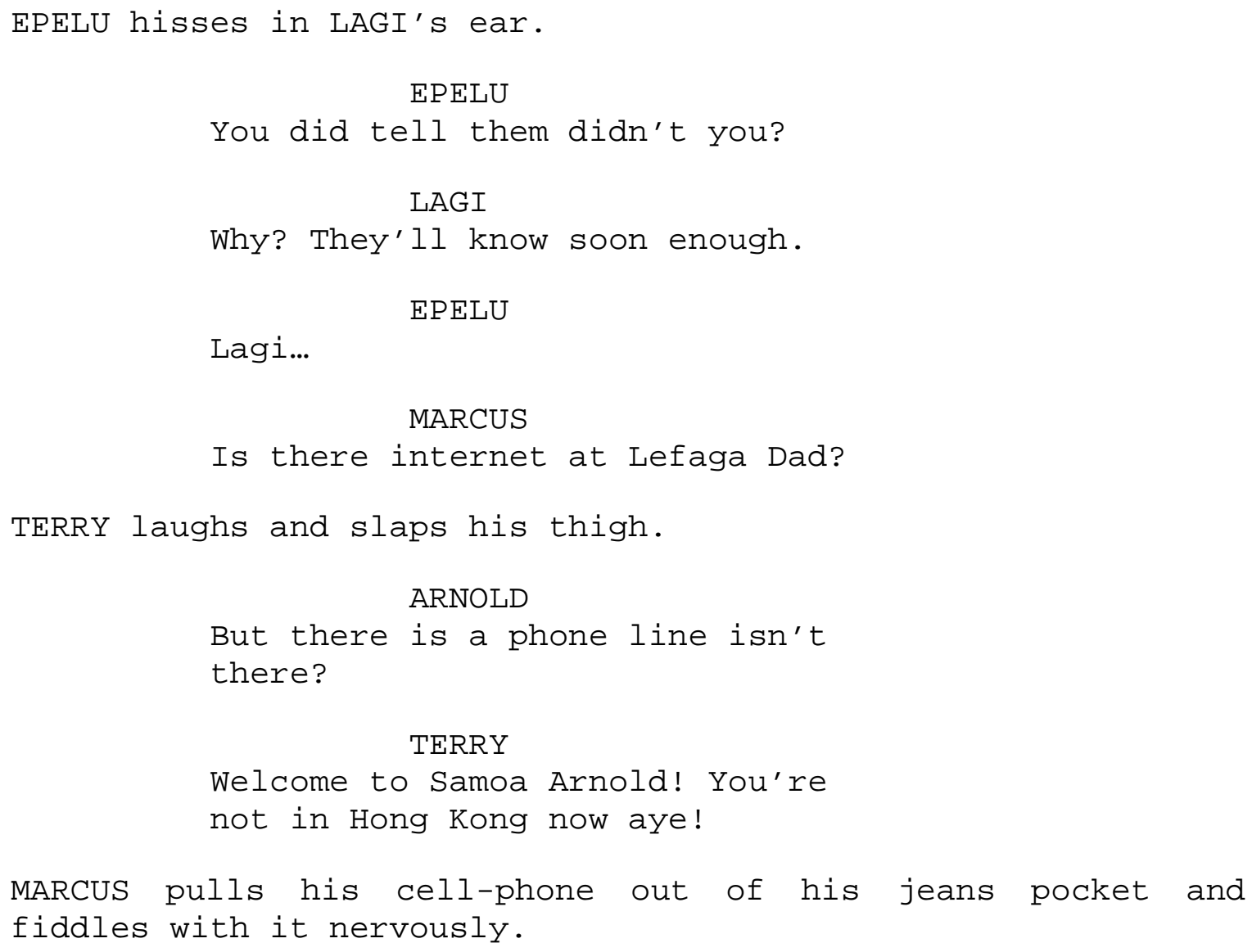

MARCUS pulls his cell-phone out of his jeans pocket and fiddles with it nervously.

CUT TO:

41 INT. SAMOAN VILLAGE KIOSK - NIGHT

Two crates of Vailima beer are stacked on the counter.

ORLANDO pulls out crumpled notes from his shirt pocket. The shopkeeper is a tall and muscular fa'afafine dressed in a purple leotard and leopard print lava lava.

SHOPKEEPER

Anything else handsome?

ORLANDO eyes a telephone hanging on the wall behind the counter.

ORLANDO

No. That's everything. Keep the

change. 
ORLANDO winks at the shopkeeper and carries the crates out to the van.

42 EXT. TRAVELLING, LEFAGA VILLAGE ROAD - NIGHT

The green van drives slowly across a ford in the river. On the other side there is a faded and rusted blue sign that says 'Welcome to Lefaga'.

CUT TO:

43 EXT. TRAVELLING, LEFAGA VILLAGE ROAD - NIGHT

The green van winds down a narrow metal road past estuary and mangroves, lamp lit fale dotted amongst green, stony beach front, the malae, church etc until it gets to the end of the road and to the biggest fale in the village and stops.

LAGI looks tentatively out the window surveying her surroundings.

LAGI squints and tries to make out familiar landmarks in the dark.

MELESINA clumsily crawls over to the van door, trying to get out in a hurry.

$$
\text { MELESINA }
$$

Toilet!

$$
\text { LAFAELE }
$$

Follow me.

Everyone clambers out of the van and begins to stretch, unpack bags. LAGI is a little dazed and sits in the van. ORLANDO mills around nervously.

LINE rushes up to the new arrivals followed by saane.

$$
\text { LINE }
$$

Oka se mea! Terry! Oh, and Lucy!

What a wonderful surprise. 
LINE gives TERRY a huge hug, squashing him into her large bosom. She comes up to his chest. This hug is followed by the same for LUCY. SAANE follows suite with the hugging process.

\section{LINE}

And Mr. Handsome, is MARCUS?

LINE then notices EPELU.

\section{LINE}

Epelu? This IS a surprise.

LAGI hears LINE's voice and climbs out of the van.

LAGI

Line.

LINE takes one look at LAGI and is stops still.

LINE regains her composure and spits in LAGI's face.

LINE

How dare you!

LAGI is stunned. So is everyone else and there is the sound of a collective sharp intake of breath.

LAGI regains her composure, wipes the spittle from her eye and slaps LINE hard across the face.

LINE launches herself onto to LAGI and the fight is all on.

In a split second, the pair have wrestled each other to the ground before anyone else has realized what is going on.

MELESINA

Aunty!

Line??

ORLANDO/ LAFAELE/ SAANE

ARNOLD moves away from the action and giggles into his hand. LUCY and MELESINA try to stop the pair from fighting.

TERRY stands stock-still and then joins in to break up the fight. 


\section{EPELU \\ STOP THIS NOW!}

LINE and LAGI stop at the sound of EPELU's booming voice. A short reprieve ended by the dull smack of LAGI's fist against LINE's jaw.

LINE is knocked out cold and hits the ground.

\section{LAGI}

Look what you made me do!

44

EXT. TUI'S PIG STY - NIGHT

TUI is straddling a pig pressing down on its throat with his knee on a long piece of wood. The pig is squealing madly and squirming for life.

MAKO comes running behind him.

MAKO

Tui! (beat) Tui! It's Lagi! It's

Lagi!

TUI

What?

TUI accidentally lets up on the pig. It wiggles free and is off into the bush, squawking the whole way.

MAKO

She beat Line up - in a fight!

MAKO's eyes are as wide as saucers.

TUI

Who?

MAKO

Lagi!

TUI is temporarily shocked. He gets to his feet, grabs a shovel that is propped up against the fale wall and runs off down a well-worn mud path.

TUI calls behind him to MAKO 
TUI

(O.S) Just going to fix the pipe

for the toilet...!

CUT TO:

45

INT. TUI'S FALE - NIGHT

TUI is frantically digging through a large wooden chest, bathed in the soft glow of a hurricane lamp.

TUI finds what he is after, a royal blue velvet lava lava.

TUI wraps this around himself and smoothes down his hair with the wet palm of his hand.

TUI strings a gold Crucifix on a chain around his neck.

He puts on a long sleeved shirt to complete the picture.

TUI takes a deep breath in...and...out.

As an afterthought, TUI reaches up into the fale rafters without looking, pulls down a bible and tucks it under his arm as he strolls down the path towards the main fale.

46 INT. TAFILI COOKING FALE - NIGHT

LAGI, changed into lava lava and t-shirt, rummages around the cooking fale looking for teabags. From the back, she looks identical to LINE.

TUI comes into the fale.

TUI

I can't believe it. I can't

believe that she would come back?

What does she think she's doing?

LAGI turns around. TUI looks like he has seen a ghost.

LAGI

Making some tea. 
TUI

Lagi!

LAGI

Tui. (beat) Still can't tell us

apart after all these years?

TUI

No, no...

An uneasy silence. LAGI moves first and turns her back on TUI to fill up a large kettle. TUI turns to walk out of the fale.

TERRY and ORLANDO walk in carrying crates of Vailima.

TUI

Terry? Malo! Manuia Malaga!

TERRY

Malo Tui! You still got my pig -

Arnie?

TUI

Oh, had to let that one go Terry...

TERRY

Oh well, good to see you Uncle!

TERRY pats TUI on the back and hands him a bottle of beer. TUI's hands are shaking so much that he spills some beer down his shirt as he goes to drink it.

TUI

I'll just go and find Line.

TUI scuttles away.

LAGI, still at the sink, with her back turned, starts nervously wringing her hands under the running tap. The knuckles on her right hand are looking puffy and swollen.

47 INT. TAFILI UMU HOUSE - NIGHT

LAFAELE is scraping long $\mathrm{Ti}$ plant leaves into a bowl. ORLANDO stands smoking above him. 


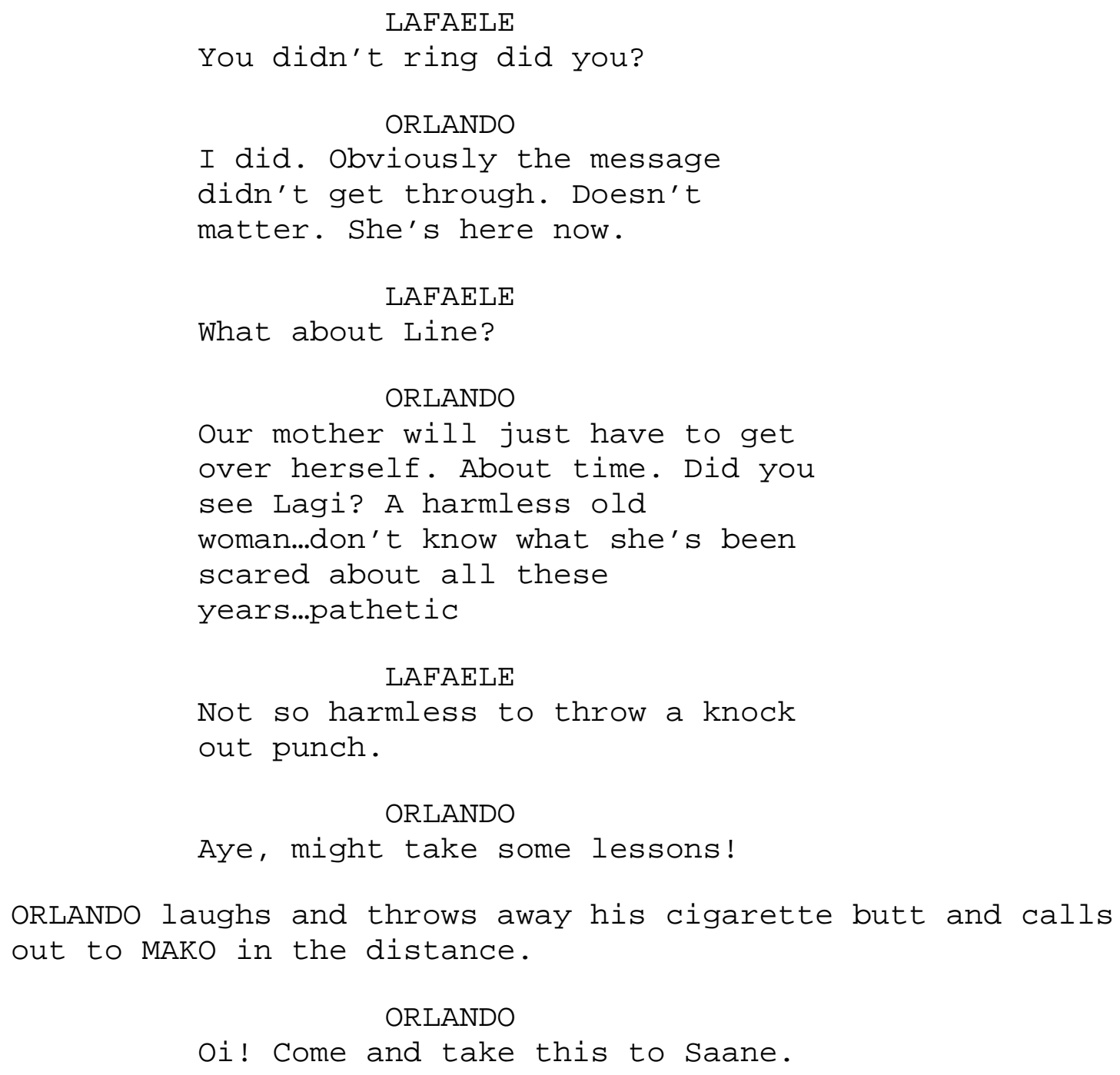


MARCUS is surprised to see one of him as a young boy with a happy looking LUCY and TERRY.

LUCY is busy unpacking and hanging up curtains over a curtain line to create the illusion of privacy.

TERRY is drinking beer outside on the step. A trio of three young boys squash together on a step watching his every move.

TUI comes up behind the fale and peers in at LINE from the window. No one sees him.

MAKO dashes through the door with a bowl of $\mathrm{Ti}$ leaves.

SAANE takes the bowl and presses the leaves down along the side of LINE's face. There is the faintest sign of bruising.

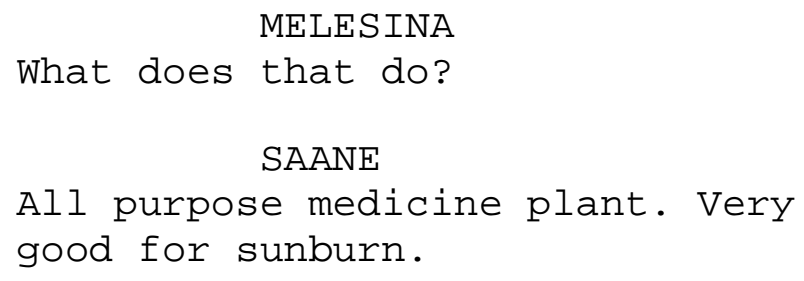

LINE whimpers louder every time SAANE presses down on her face.

MELESINA

Do you need any help.

SAANE

No, this will be fine.

SAANE lifts the leaves off LINE's face. There is now a huge purple bruise across LINE's jaw-line.

\section{MELESINA}

Whoa! Is it supposed to do that?

SAANE nods.

EPELU sees LAGI wander past off on to the beach by herself. She is wringing her hands and carries her notebook under her arm.

\section{EPELU}

Saane, I thought, under the

circumstances, we might do a lotu 
tonight before everyone goes to
sleep.

SAANE

Okay Uncle.

EPELU

Everyone, just a short prayer of

thanks for a...safe...arrival.

SAANE gets up and switches the main fale light off.

49 EXT. LEFAGA BEACH - NIGHT

LAGI looks back at the fale palagi as the light is switched off. A soft glow comes from a bedside light next to LINE.

LAGI studies the bowed heads of her family outlined like portraits by the windows.

LAGI's gaze zeros in on TUI who sits on a tree stump outside the fale listening to a quietly sung hymn.

The bedside light is turned out and the fale is bathed in darkness as the hymn ends.

\section{INT. TUSITALA'S FALE - MIDNIGHT}

A scratching sound in the darkness.

TUSITALA lies deep in sleep on a fala (woven mat), his head resting on a traditional wooden Samoan neck rest.

TUSITALA cradles a plastic wall clock made in the image of Jesus with arms reaching out to his flock.

A hand stretches out and shakes TUSITALA's knee.

TUSITALA wakes with a snort. The clock clanks to the floor. LINE creeps into the fale.

\section{LINE}

Tusitala! 


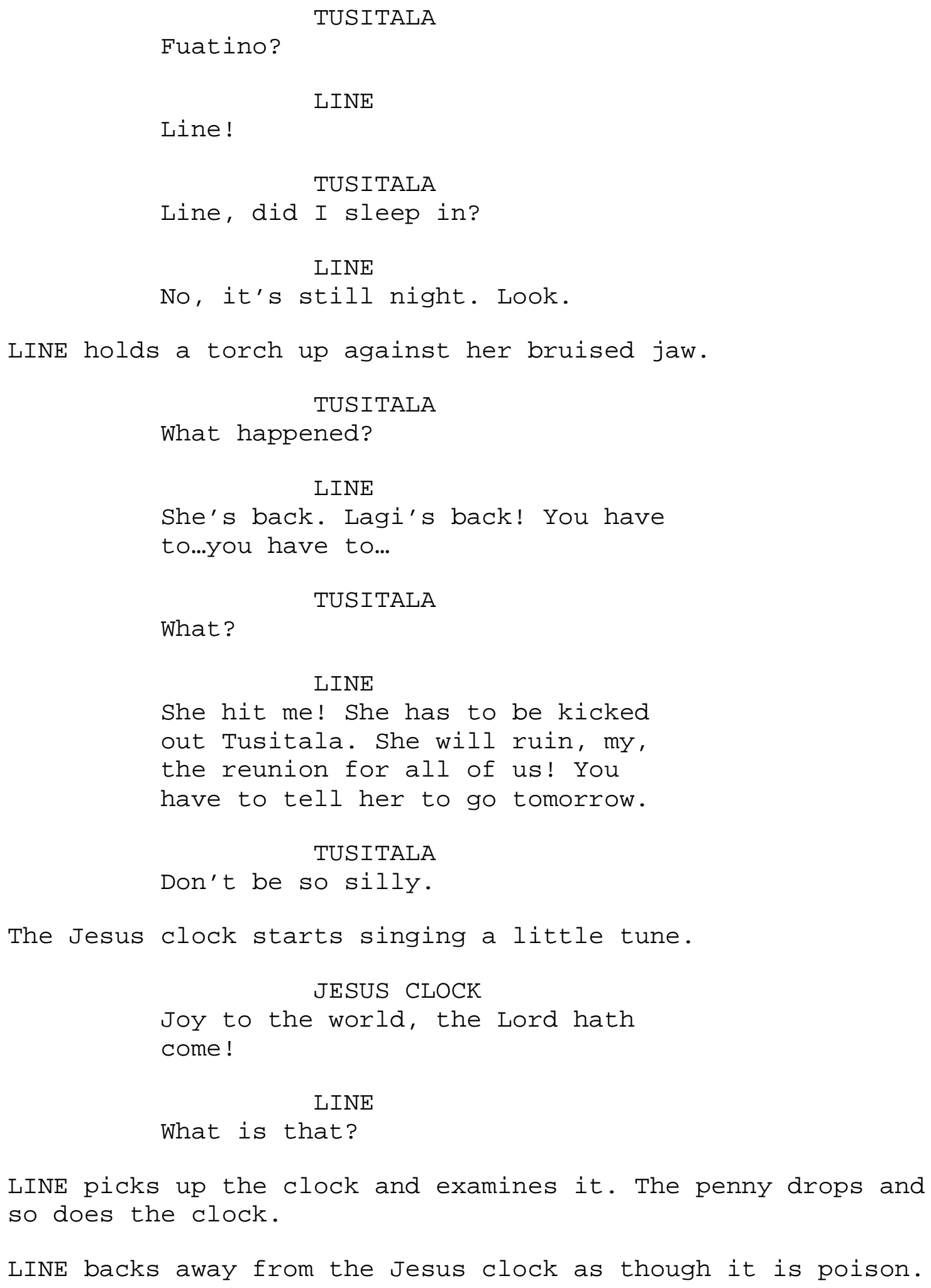

LINE picks up the clock and examines it. The penny drops and so does the clock.

LINE backs away from the Jesus clock as though it is poison. 


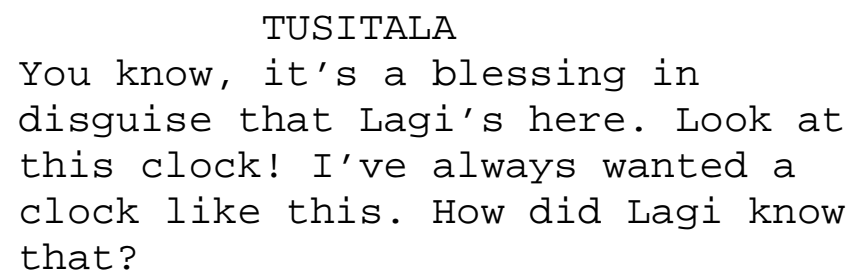

TUSITALA nimbly presses some buttons on the side of the clock. Jesus' outstretched arms move up and down and he begins to sing.

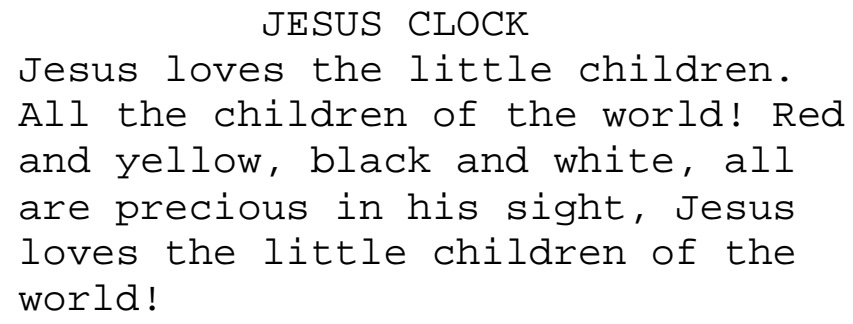

LINE backs out of the fale in disgust, leaving TUSITALA to his clock.

51 INT. LEFAGA CATHOLIC CATHEDRAL - DAWN

"Day One"

SAANE stands gazing up at Jesus strung out on his crucifix at the altar of the overpowering Lefaga Catholic Cathedral. She gets tapped on the shoulder and SAANE spins around nervously.

\section{SAANE}

Oi! You gave me a fright!

SAANE is confronted by ORLANDO. Orlando is wearing catechist robes and he has a ukulele strung over his shoulder. ORLANDO picks and sucks at his teeth with a palm leaf frond. He hands SAANE an envelope.

\section{SAANE}

What is it?

$$
\text { ORLANDO }
$$

Open it. Find out.

SAANE tears open the envelope. She glances inside at the contents. 


\section{SAANE}

You prick! I can't believe you're my brother.

\section{ORLANDO}

You want something. I want something. Our lives are simple like that.

\section{SAANE}

What is it you want this time?

More money?

\section{ORLANDO}

No, not everything's about money Saane. The Tafili title. That's all I want.

\section{SAANE}

You don't deserve it you little arse-licker. You have to work harder than that orlando

ORLANDO

Whatever. I'm sure Glennis' employers would like to know why she spends so much time down here on weekends. Anyway, I think it's just as well that Lagi's shown up.

SAANE

Why?

$$
\text { ORLANDO }
$$

I wonder if she cares to know that the title is hers to claim back if she wishes?

\section{SAANE}

She wouldn't...

ORLANDO

Wouldn't she?

SAANE

(beat) Orlando, I kicked you around the malae when we were young and I'll do the same to you 
now so you'd better watch your back. You're not getting the title. End of story.

SAANE pulls the toothpick from ORLANDO's mouth and saunters down and out of the cathedral doors.

The dawn streams in on ORLANDO as the doors open giving him a halo of light before the door slams shut and he is bathed in darkness.

\section{EXT. LEFAGA VILLAGE, MAIN FALE - MORNING}

LINE opens an eye and spies two lizards running across the ceiling. A drop of water leaking from the ceiling lands squarely into her eye accelerating her into a blinking and eye-rubbing frenzy.

LINE sits on a four-poster double bed waking from sleep. The bed looks like it was inherited from the Victorian age. LINE's jaw is a deep purple.

LINE is distracted by a man's booming voice in the distance. She turns to look out the window immediately next to her bed and sees a long procession of people dressed in yellow and green uniforms snaking down the narrow road towards the fale.

TUSITALA leads the procession. Another matai is replying at the end of the road just beyond complete with his own band of welcomers.

TERRY stands amongst the people next to LUCY and LAGI, EPELU and ARNOLD and MARCUS.

LINE sighs and covers her face back up with a sheet. She closes her eyes.

\section{LINE}

Please Jesus, make her go away...I

promise I'll be a better person...to

people...just make her go away...

Young women whisk ie toga (fine mats), trays of corned beef, and envelopes of money and reams of fabric back and forth between the two groups. 
Half of the group is privy to the logic of the exchange and thus chatters amongst themselves or gets some shut-eye.

For others, mostly the taller and less tanned group members, this is a new and intriguing experience and they cluster together, a little nervous.

LINE flicks the sheet back off her face and looks out the window again. LAGI is still there.

\section{LINE}

Fuck!

53 INT. TAFILI FALE'O'O - DAY

Matai sit around the posts of the fale o'O. TERRY and ARNOLD sit on opposing posts.

LAGI sits next to MELESINA, LUCY and MARCUS. EPELU sits on a wooden chair at the head of the fale next to TUSITALA.

TUSITALA is served a food mat full to the brim by a young girl.

The rest of the matai are served by the girl army .

ARNOLD plays with his cell phone. He is trying to get a signal. He almost succeeds.

TUSITALA begins to say a prayer.

$$
\text { TUSITALA }
$$

Let us pray. It is a wonderful day

for the Tafili a'iga to be

together here in our village of

origin. We pray for each and every

member of our $a^{\prime}$ iga and we pray

especially for Lagi and her//

ARNOLD

//Arrrgghhh!

ARNOLD who has been stretching around absentmindedly trying to get his cell phone signal, has gotten up, but with pins and needles in his leg, has stumbled around the fale and slipped on a food mat and gone flying out of the side of the fale onto the ground below. 
LAGI shrinks with embarrassment.

LINE happens to be walking past carrying food supplies. LINE smiles to herself as she walks past the ensuing commotion.

\section{EXT. SUGARCANE FIELD - DAY}

LAGI is on a mission. She rubs and itches at her hands agitatedly whilst striding out through the sugarcane field. LAGI is heading for a small run down looking fale in the distance.

\section{CUT TO:}

\section{INT. TAFILI PLANTATION FALE - DAY}

Eddie Lovette's cover of 'Just One Look' plays through a small ghetto blaster in the corner of a dusty little ole' fale.

The fale is decorated with the 'Boys' - NIKI (17), ASEMA (19), and TALAVOU (18) who are getting blazed. The Boys harmonise badly with Eddie Lovette.

LAGI bursts through the doorway of the fale. The Boys scramble to cover up their activities.

NIKI sweeps the dope stash under the fala (mat) and fiddles with the ghetto blaster and associated wiring.

TALAVOU quickly gets out a large cabin bread tin and fawns at it.

ASEMA just closes his eyes and pretends to be asleep on the floor curled up in the fetal position.

\section{LAGI}

(under her breath) Some things never change...Hey, hey, don't worry. I'm looking for something and I think I just found it.

The Boys are clearly still nervous. 
LAGI

I have money .

ASEMA opens an eye at the mention of money.

56 INT. LEFAGA METHODIST CHURCH HALL - DAY

The first feast. LINE is calm and in control and overseeing the feast.

Young girls exit the kitchen carrying steaming hot cups of tea and pudding to a top table of Mafutaga V.I.Ps - mostly the matais from the welcoming procession, the Methodist faife'au (church minister) and the Catholic patele (priest).

Band members are setting up their instruments on stage. ORLANDO can be spotted directing the set-up.

Village kids and visiting overseas kids play together in front of the stage, both enjoying temporary freedom from the adults gaze.

MARCUS hides behind his camera taking shots of people. He comes across LAFAELE and SAANE sitting at a table with others. MARCUS takes a picture of the siblings.

EPELU stands to address the hall.

EPELU

Before we officially begin our

mafutaga games and activities, let

us pray. Quietly and quickly.

(beat) AMEN!

CUT TO:

57 EXT. TAFILI COOKING FALE - DAY

A machete swiftly chops the head off a cooked suckling pig that falls into a waiting dish. 
CUT TO:

58

EXT. LEFAGA VILLAGE MALAE - DAY

LINE strides quickly across the malae and motions to a pack of pasty looking Korean teenaged boys playing hackie sack.

\section{LINE}

Hey, hey. Come here.

The teenagers look a little anxious but stop their game.

LINE

You like girls?

The teenagers look even more anxious. Is this a trick question? A couple of them nod in agreement.

LINE

You want to go to the nightclub

tonight? Yeah? Good. I put a bar

tab for the winners - \$200 tala.

Pretty good reunion aye?

The boys look impressed. A brave boy, KEN (17), speaks up.

KEN

But we're playing the team with

that rugby player in it. He's a

legend. I saw him practicing.

LINE

Don't worry about him. Aim for the

old lady next to him. She's the

secret weapon.

LINE points over to Tafilis where MARCUS and TERRY are

practicing. MARCUS weakly serves the ball and TERRY smashes it over the net.

LAGI is shaking her head at ARNOLD who has come jogging out of the fale palagi wearing sparkling new sports wear and a checkered sweat band on his head.

LUCY follows ARNOLD dressed in a floaty print dress. She looks like a tropical Venus.

TERRY sees LUCY and spikes the ball down hard into the dirt. 
59 EXT. LEFAGA MANGROVES - DAY

LAGI takes a quick toke from a joint as she hides in the mangroves just out of sight from the village malae and volleyball court.

LAGI relaxes with each puff. She starts to jog on the spot and stretch out her arms and shoulders.

60 EXT. LEFAGA VILLAGE MALAE - DAY

LINE, wearing a bright orange t-shirt and lavalava leads the chant for mafutaga volleyball team who are hunched over and huddled together in a semi-scrum position.

The team is made up of MARCUS, TERRY, SAANE, LAFAELE, ORLANDO and ARNOLD.

\section{LINE}

We can smash this team. They're

Alfred's lot. Wimps.

LAGI

Smash them aye? We'll see. Right,

remember the chant Line? - Who

are, who are, who are we?

VOLLEYBALL TEAM

Who are, who are, who are we?

LINE

Are we monkeys?

VOLLEYBALL TEAM

NO!

LINE

Are we horses?

VOLLEYBALL TEAM

NO!

LINE

Are we lions?

VOLLEYBALL TEAM

YES! (Loud lion roaring imitation) 
CUT TO:

TERRY clicks his neck on both sides and spits into the ground.

CUT TO:

61 EXT. LEFAGA VILLAGE MALAE - DAY

The umpire blows the whistle for the volleyball game to begin.

The opposition team comes to life and are looking extremely organized and totally with game.

CUT TO:

62 EXT. LEFAGA VILLAGE MALAE - DAY

The volleyball is spiked down hard into LAGI's team's territory right towards LAGI.

LAGI covers her head and sticks out her arm. The ball crashes down beside her.

TERRY

Come on LAGI! Marcus - serve!

TERRY chucks the ball hard at MARCUS.

MARCUS serves the ball short and it bounces off the net and back into LAFAELE who catches it.

LUCY and MELESINA sit under a tree at the sidelines.

MELESINA

Come on team! Go Marcus!

TERRY

Whatta you doing son?

ARNOLD

Good try Marcus. 


\author{
Go Arnold!
}

TERRY is already sweating hard. He wipes sweat from his brow and his eyes narrow in on ARNOLD.

KEN serves the ball deep. LAFAELE digs it and TERRY and ARNOLD both go for it. TERRY knocks ARNOLD over.

The ball hits the ground.

KEN serves again. ORLANDO returns. KEN sets and another team member spikes the ball down hard at LAGI again. This time it hits LAGI on the arm.

\title{
LAGI
}

Aye!

\section{LINE}

Can't handle the pace Lagi?

There's a lot more games on today...

\section{CUT TO:}

63 EXT. LEFAGA LAGOON - DAY

64 MONTAGE :

A) TERRY and MARCUS are paddling at full capacity across the lagoon in an outrigger canoe. TERRY is bare-chested with a t-shirt wrapped around his head ninja style. They are racing against an Olympic pair of Jonah Lomu look-a-like canoeing twins. TERRY and MARCUS lag behind.

B) LUCY, MELESINA and ARNOLD are attempting to weave baskets. MAKO sits beside them and as they struggle to make two rows of weaving, whips up a basket, hat, pair of jandals.

C) TUSITALA supervises young men thatching the roof of a traditional fale. LAFAELE leans against the maroon container smoking a cigarette. He absentmindedly drops the butt into a pile of dry thatching which bursts into flames instantly. 
D) LINE and LAGI are ordering competing teams of young women in the church hall. LINE's team finishes the serving of the matai, pipping LAGI's girls at the post.

MARCUS is watching the rugby action down below in the village perched on a rock amongst a field of sugarcane. The sugarcane rustles and MARCUS hears the sound of people making their way towards him. It is the Boys.

NIKI

Malo Marcus

MARCUS

Hey •

TALAVOU

Your dad played for Manu Samoa

aye?

MARCUS

Yeah.

NIKI

You play rugby Marcus?

MARCUS

Nah. (beat) Oh yeah.

NIKI pulls out a joint and lights up. He offers it to MARCUS. MARCUS looks at it tentatively. There is a commotion on the malae below. MARCUS glances down to see TERRY and ARNOLD playing a game of one-on-one volleyball that is looking more like progressing into a battle of the gladiators. Both men have their tops off. LUCY is yelling at them both.

LUCY

If you're going to both be such morons, at least put some sunscreen on!

ASEMA makes remarks about LUCY in Samoan whilst making lewd grinding movements. 


\section{ASEMA}

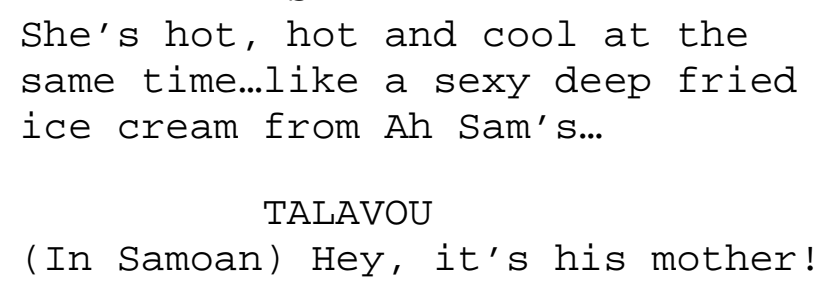

TALAVOU

(In Samoan) Hey, it's his mother!

The Boys crack up laughing. NIKI pats MARCUS on the back and leads him through the sugarcane field.

\section{NIKI}

Hey, wanna see something funny?

The heavens open and rain starts to pour down in buckets. The Boys, all giggling, usher MARCUS along a track towards the rainforest.

66 EXT. TUI'S PIGSTY - DAY

ASEMA stands feeding the pigs at TUI's pigsty. It is still pouring with rain. ASEMA looks around him and, as the coast is clear, whistles two short whistles.

Out of the bush sneaks NIKI, TALAVOU and MARCUS. MARCUS looks anxious.

The Boys snake their way towards TUI's fale.

\section{CUT TO:}

\section{INT. TUI'S FALE - DAY}

A hand reaches up into the rafters in TUI's fale. NIKI pulls down a very large plastic container filled with taba'a, Samoan tobacco.

MARCUS looks around the fale rafters at old photos, black and white and some coloured but fading yellow. He recognizes one of a photo of TERRY in the Manu samoa official rugby photo.

NIKI is tipping a bag of weed into the taba'a.

NIKI shakes the container, puts the lid back on and signals to MARCUS to make his way back outside. 


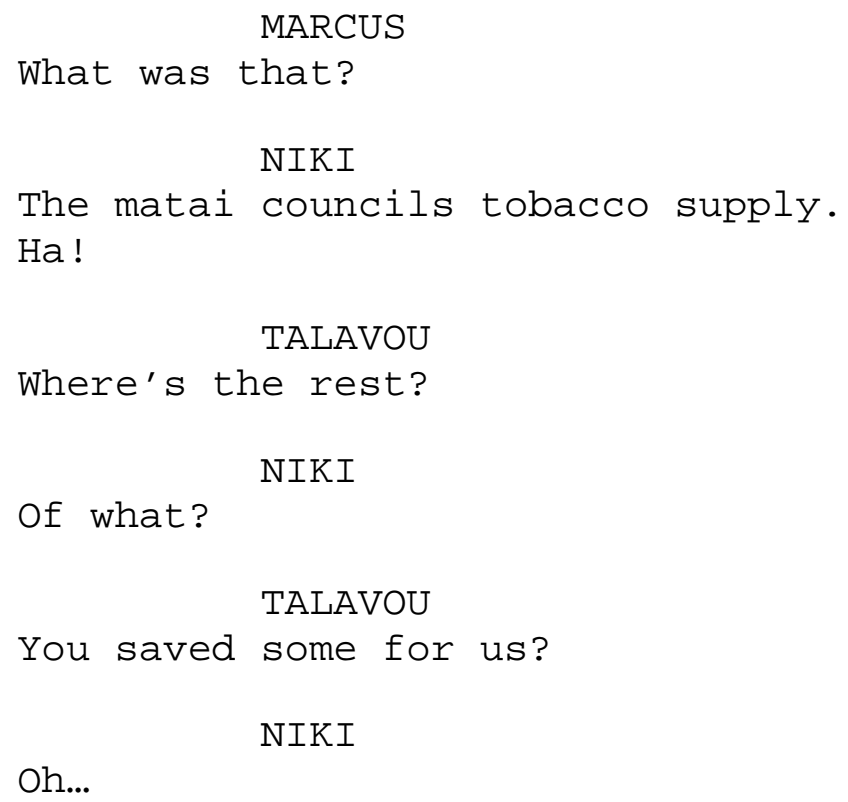


69 INT. LEFAGA METHODIST CHURCH HALL - DUSK

EPELU sits at a table with men similarly aged talking.

MELESINA and LUCY are milling through the hall with others looking at the family tree across the walls.

LUCY

Honestly Mele, there are far too many of you Tafilis around.

MELESINA

I know, we're all breeders. Look at this one - 13 kids! Can you imagine, 13 kids?

\section{LUCY}

There's not really much to do around here though is there? Did you send them your photo over?

MELESINA

No, must have been Terry. He seems to keep all of the family photos together.

LUCY

Yes, the one unexpected bonus of being his wife. He always did the photo albums. Oops, here she comes.

LAGI is striding over to the group.

LAGI

Where's Terry?

LUCY

Not sure.

LAGI

He needs to get ready for the hike tomorrow. Where's Marcus?

LUCY

Not sure. 


\section{LAGI}

Honestly Lucy! They both need to go as a pair.

LUCY

Oh, yes, I think Arnold was

talking about going with Marcus

too.

LAGI

No he's not. I've already put him with Lafaele. You play suipi Melesina?

MELESINA

Not since I was a kid.

LAGI

Good. We're playing in 10 minutes. Get yourself comfortable.

CUT TO:

70 INT. LEGAGA METHODIST CHURCH HALL - NIGHT

LINE pins up an A3 sheet of paper on the wall next to three tables set up for card playing.

Two tables are full with four players each.

The third table seats ORLANDO and SAANE.

ORLANDO is casino shuffling a large deck of cards.

LAGI and MELESINA walk up to the table and sit down.

LINE turns around and sees that LAGI is about to play. She taps ORLANDO's shoulder. ORLANDO ignores this at first. LINE taps more forcefully. ORLANDO rolls his eyes, stands up and LINE sits down at the table.

LINE motions to a girl in the distance, all the while, eyes dead on LAGI.

The girl brings a tray with cups of piping hot Koko samoa to the table and serves it. 
LAGI takes hers and sips. Too hot! Ouch, she's burnt her tongue.

LINE starts to casino shuffle the deck even more impressively than ORLANDO.

No one has said a word. MELESINA goes to say something but stops. The mood is tense to say the least.

\title{
LINE
}

Cut.

LAGI cuts the pack of cards, thinks a bit and then throws some notes on the table.

LINE raises an eyebrow.

\author{
LINE \\ Orlando.
}

ORLANDO, standing to the side, shakes his head, dips into his shirt pocket and digs out some crumpled notes. He hands these to LINE who tosses them on to the table.

LINE begins to deal the cards. MELESINA reaches forward to take the cards.

\section{LAGI \\ $\mathrm{DON}^{\prime} \mathrm{T} !$}

MELESINA pulls her hand back, frightened.

LAGI

We don't touch the cards until

they're fully dealt.

SAANE winks at MELESINA who giggles. LAGI gives MELESINA a deadly look.

CUT TO:

71 INT. LEFAGA METHODIST CHURCH HALL - NIGHT

A large crowd has gathered around the table where LINE and LAGI are locked in battle via the card game of Suipi.

A bundle of cash is piled up on the table. 
It is now just LAGI versus LINE playing. SAANE is giving MELESINA a foot massage in the corner of the hall.

EPELU breaks away from his men's group finally and comes over to see what all of the fuss is about.

TUI walks into the hall with TUSITALA who stands next to EPELU.

TUI carries a large see-through plastic container filled with taba' a Samoa.

MARCUS and The Boys slip in the hall and sit up on the stage looking eagerly at TUI and his taba'a Samoa.

EPELU

Honestly! This is nonsense! Lagi!

TUSITALA

No. Let them be. This is

important.

TUI

Line, Line...

TUI whispers in LINE's ear.

TUI

We can't afford this? Where is

this money coming from?

LINE shoos TUI away.

LINE

Go and feed your pigs!

TUI, dejected, goes to leave.

LINE

But leave that.

LINE points to the taba' a Samoa. LAGI deals the cards and throws some more money on the table as she picks her cards. LINE is nervous as she consults her own cards.

LINE

Break time! Lagi, taba'a? 
LAGI looks slyly at LINE, knowing that she has an advantage. LAGI

Roll it up.

MARCUS and The Boys all lean forward where they sit on the stage.

CUT TO:

72 INT. LEFAGA METHODIST CHURCH HALL - NIGHT

There is no one else left in the hall except for LINE and LAGI, MARCUS and The Boys.

The Boys are dancing like maniacs up on stage to a Justin Timberlake track. MARCUS sits at the drum kit doing air drumming with his eyes closed.

LINE and LAGI smoke away on the taba'a, laughing and joking.

LINE

That's it. That's all I've got and

you've won it all now. Hahahaha!

LAGI

That's funny! I've got everything

of yours!

LINE

I should have bet Tui. How much

would he have been worth?

LAGI

Fifty tala?

LINE

Fifty? I was thinking more like ten!

The sisters laugh and laugh until LINE flops forward in her chair. LAGI sweeps up the money from the table, humming to herself and dumps it into her handbag.

LAGI gets up from the table. 
LAGI

Marcus! Marcus! Bedtime!

MARCUS awakens from his trance and follows LAGI. LAGI

switches the power off in the hall and stumbles out down the steps.

73 INT. TAFILI FALE PALAGI - DARKEST NIGHT

"Day Two"

LAGI hums as she steps over sleeping bodies. She stumbles and trips over someone who gives a muffled yell.

LAGI falls onto her mattress smiling and is snoring

immediately.

74 EXT. LEFAGA VILLAGE ROAD - DAWN

Dawn has bought a new visitor to Lefaga. Smack in the middle of the road lies a crimson freight container.

Plantation workers are already up and weaving their way around the container as they walk along the road.

A village bus reverses its way back down the road, away from the container.

75 INT. TAFILI FALE PALAGI - MORNING

LAGI is up. Cheerful and humming, she is busily tidying and folding washing.

Everyone else still sleeps. LAGI tours the fale, gently kicking people as they sleep.

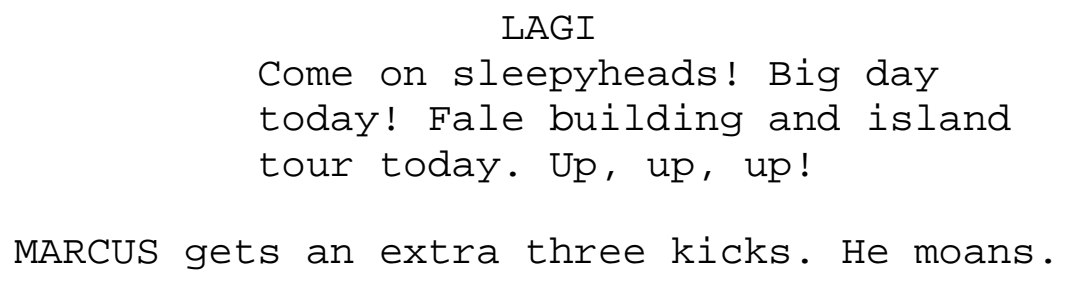


TERRY jogs into the fale. He is sweating and has his shirt wrapped around his head.

\section{TERRY \\ Morning all!}

A collective moan from the floor. LUCY throws a jandal at TERRY.

\section{TERRY}

Son, better get up and get going .

We're in the plantation hike

today. You and me in a team.

LAGI

The hike's tomorrow Terry.

TERRY

Nah, some joker's blocked the road

with a container so we're doing

the hike instead. Arnold, you up

for it?

ARNOLD

A hike? In this heat?

TERRY

I'll put you down then.

76 EXT. TUI'S PIG STY - MORNING

LINE and TUI stand arguing whilst TUI throws food in for the pigs.

LINE is dressed in her best pule tasi and looks like she is going to church.

TUI

You lost everything?

\section{LINE}

Look, I know her. I know what her

plan is. She wants to come back

here and take everything that I've

worked for! It's not going to

happen . 
TUI

The whole thing is so childish

Line. No one is enjoying this time

together because of what you're

doing.

LINE

Me? What I'm doing? We wouldn't be

in this mess if it wasn't for you! (beat) You still have feelings for her don't you? Don't you!

TUI

of course not.

\section{LINE}

Good. Because we need to be in church in half and hour so get dressed.

TUI

What for?

LINE

We're renewing our vows.

TUI

But we're not even married Line?

LINE

Well we're getting married then

Tui! Okay? Are you alright with

that?

TUI shakes his head. LINE is looking totally deranged.

77 INT. LEFAGA METHODIST CHURCH HALL - MORNING

LAGI is serving herself some creamy scrambled eggs from a big buffet spread in the hall. People mill around, sitting and eating .

MAKO runs up to LAGI and gives her a piece of paper. She opens it and reads it, places her plate on the table and walks towards the church door. 
CUT TO:

78

EXT. TAFILI FALE PALAGI - MORNING

EPELU is shaving at the pipe just outside the fale. He hears LAGI's voice and cuts himself.

LAGI

Did you know about this?

LAGI walks over waving a piece of paper in the air.

EPELU

What is it?

LAGI

Line and Tui - YYou are invited to

witness Line and Tui renew their

love for one another'. It's this

morning!

EPELU continues shaving.

LAGI

Well?

EPELU

Well what?

LAGI

Aren't you going to do anything?

EPELU

Like what?

LAGI

Like stop it? She's just doing

this to get at me!

EPELU stops shaving.

EPELU

Have you noticed Lagi, that since

we arrived two days ago- you have

assaulted Line and made her gamble

away all of her money and

generally been very unpleasant to

everybody. I just don't recognize

you Lagi. (beat) I'm going into 
town today by myself. Lafaele's

taking me.

LAGI screws the piece of paper up, stamps her foot in frustration, turns on her heel and stomps off.

79 INT. LEFAGA METHODIST CHURCH - MORNING

A photograph flash. The photograph captures LINE and TUI squashed next to each other. TUSITALA smiles genuinely next to LINE and LAGI is smirking in the background.

CUT TO:

80 INT. LEFAFA METHODIST CHURCH HALL - MORNING

A hand places the new photograph up on the family tree with a drawing pin in the middle. The photograph swings sideways.

81 EXT. LEFAGA BEACH - MORNING

LUCY and MELESINA walk arm in arm along the stony beach. SAANE walks next to LUCY.

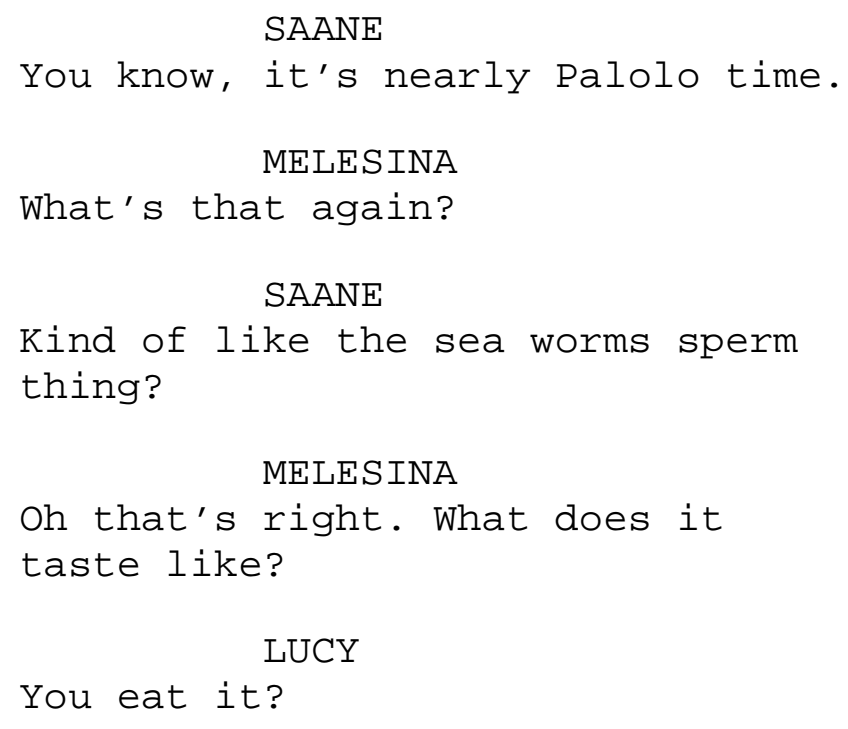$$
\text { . }
$$ 


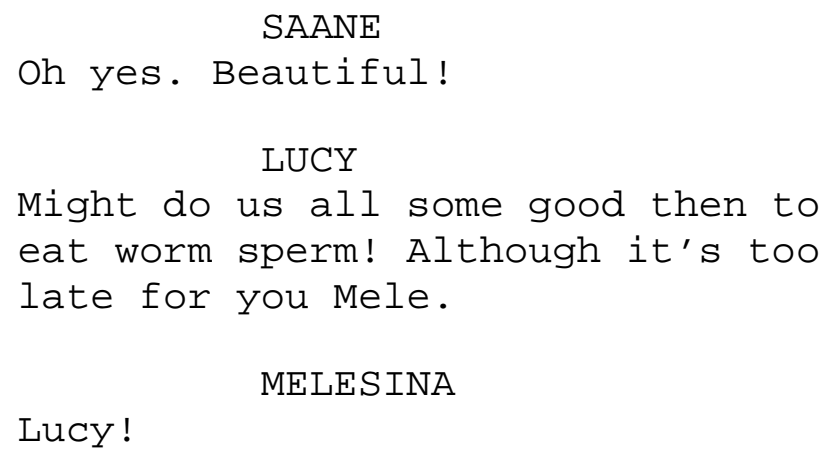

SAANE stops to pick up a red plastic container.

SAANE

So much rubbish around here now.

Used to be so clean.

SAANE shakes the container, hears something rattle inside and opens it up. She pulls out a plastic wrapped item, sniffs at it and then unwraps it.

\author{
MELESINA \\ What is it?
}

SAANE shows MELESINA and LUCY the photos inside the bag. They are of MELESINA. MELESINA picks out a black and white photo of a young woman, a baby and a young boy.

MELESINA

I think that's Terry! Do you know the woman?

SAANE nods.

82 EXT. FALE BUILDING SITE - MORNING

TUSITALA stands in front of a flat site amongst the bush.

TUSITALA is giving an animated lecture to a large group of mafutaga members who stand around him listening intently.

TERRY stands up the front of the group with a small axe resting over his shoulder.

TUI sits on a small yellow digger clearing away the site. 
TUSITALA

So, by the end of this week we are all going to be very, very proud of ourselves because we would have finished our fale Samoa - working together as a family like they did in the old days. Not many Samoans now even bother to learn these things. Seems to be something the Japanese are more interested in for some reason. I'm not sure but before I die, this fale will be built!

TUI smiles and continues his work. LAGI comes and joins the group, watching TUI from the corner of her eye.

MELESINA waddles in on the group. She finds LAGI and thrusts the photograph in her face.

$$
\text { MELESINA }
$$

Is this you?

\section{LAGI}

Hello. You coming to watch?

MELESINA

I said, is this you?

LAGI glances at the photograph.

$$
\begin{array}{r}
\text { MELESINA } \\
\text { It is isn't it? }
\end{array}
$$

LAGI ignores MELESINA. TUI looks over at the pair. LAGI walks off leaving MELESINA.

\section{LAGI}

What are you doing Terry? Where's

Marcus? Have you seen him at ALL

since you've been here? What kind

of a father are you? Arnold's

spent more time with him.

TERRY looks like he's been smacked in the face. LAGI then sets her eyes on TUI who has walked over to MELESINA and addresses him. 


\section{LAGI}

It was you wasn't it! You couldn't stay out of it! Where did you get them from?

TUSITALA makes an attempt to reclaim the focus on the task at hand.

$$
\text { TUSITALA }
$$

And like I was saying, the most important thing is that we are keeping the knowledge of an ancient art in the family. Because that's what this is about reuniting the FAMILY.

On the word 'Family', TUSITALA nods at LAGI and TUI.

TERRY explodes.

\section{TERRY}

I know you're my real mother Lagi!

I WAS old enough to remember that

I had a different mother for the

first four years of my life or did you think that I'd forgotten? You think that you can come back and fix everything now? You fucked it up the first time Lagi, why should anyone give a stuff about you now? And look at Mele, no wonder she's fucken been left by her husband she couldn't help it with a mother like you!

LAGI is speechless. MELESINA crumples, TUI steadies her.

One of the men digging a post for the fale yells out loudly. Everyone rushes over to see what is going on.

TUSITALA pushes through the group that has huddled around a hole in the ground. A human skull peeps through the dirt.

TUSITALA turns white, gasps and runs off as fast as he can towards the bush. After a confused pause, TERRY makes off after him. 
TUI brings up the rear.

TERRY and TUI catch up to TUSITALA who trips on a tree stump and falls onto his face. TERRY helps him up.

TUSITALA, out of breath and plainly scared out of his wits, utters one word before he faints.

TUSITALA

Fuatino!

TERRY feels for a pulse then listens to TUSITALA's chest but hears nothing.

$$
\text { He's dead! TERRY }
$$

TUI bends over and closes TUSITALA's eyelids.

TUI and TERRY huddle in to discuss what next.

TUI

You stay here, I'll go and get

help.

TERRY

I can carry him. He can't weigh

that much?

TUI

Okay •

TUI and TERRY look back to TUSITALA. What! He's vanished.

CUT TO:

83 EXT. LEFAGA VILLAGE ROAD - MORNING

LAFAELE sits in the idling bus pondering the container that is blocking their exit from the village.

LAGI rushes up and into the bus and pushes LAFAELE out of the drivers seat and out of the door. LAGI slams the door shut. 
LAGI starts up the bus and grinds the gears and roars the bus into life.

The bus is gaining speed as it quickly approaches the container.

EPELU, who has been taking a nap at the back of the bus, sits upright in the commotion and stumbles up the aisle once he realizes what is happening.

$$
\begin{aligned}
& \text { EPELU } \\
& \text { Lagi! Stop! }
\end{aligned}
$$

LAGI is crying wildly. She gets a fright when she hears EPELU's voice and accidentally accelerates instead of braking .

The bus roars off towards the container.

ORLANDO walks out of the container and sees the bus rattling towards him. He runs and jumps into a bush.

LAGI crashes the bus into the container. The container lurches on its side and rolls over to rest in the ditch.

A shiny white porcelain toilet falls out of the open doors next to ORLANDO who has his eyes squeezed tight and is shielding his head and vital organs.

\section{EXT. TAFILI PLANTATION TRACK - DAY}

A mock starting line and lanes are set up at the edge of a steep bushy hill that is the beginning of the plantation. A well-worn mud path winds its way through the bush.

TERRY stretches and spits into the ground. He carries a machete over his shoulder. He looks menacingly at ARNOLD who has teamed up with KEN, Korean volleyball teenager.

MARCUS and The Boys mill around.

TERRY

Come on Marcus.

MARCUS ignores TERRY. 


\section{TERRY \\ I said, come on Marcus!}

MARCUS and The Boys do a complex handshake complete with sound effects.

ARNOLD slaps MARCUS on the back.

ARNOLD

You got plenty of water there

Marcus? See you at the top!

ARNOLD whispers in MARCUS' ear and gestures to TERRY.

ARNOLD

Hard out aye!

MARCUS smiles.

TERRY

Lets go.

Hike teams line up at the start line. An air gun fires. They're off.

85 MONTAGE :

E) ARNOLD and KEN consulting a compass and map. KEN offers ARNOLD water from his water bottle

F) MARCUS struggles to keep up with TERRY who is powering through the bush and slashing at it with his machete

G) ARNOLD and KEN sight the finish line and shake each other's hands.

86 EXT. TAFILI PLANTATION - NOON

TERRY slashes wildly at bush. MARCUS sits under a tree taking a big drink of water and huffing and puffing.

TERRY

Fuck! Fuck! Fuck! They're probably

there by now! Fuck! 
MARCUS

You want some water Dad?

TERRY

Nah. Lets go.

MARCUS

Can we just have a rest of a minute.

TERRY

Come on son!

MARCUS

I'm really stuffed Dad.

TERRY considers this.

TERRY

You wait here. I'll finish the race and come back and get you aye?

MARCUS

Okay •

87 INT. TUI'S FALE - NOON

MELESINA sits on the fala with photo albums spread all around her. Her eyes are swollen from crying.

LINE sits next to MELESINA. LINE cries and wipes her nose with the edge of her t-shirt.

TUI is smoking and looking out towards the sea.

MELESINA

My husband, Robert, slept with six

other women during our marriage.

Probably more. (beat) I don't want

this baby anymore. Not with no

father around.

LINE sobs on hearing this. 
LINE

Tui, go and get Lagi. It's time to

stop all this silliness.

The Plantation Hike teams have returned to the finish line at the malae.

ARNOLD and KEN wear frangipani ula's and hold a small plastic gold cup. LUCY is taking a photo of them.

\section{LUCY}

Terry'll be pissed that you beat him Arnold.

\section{ARNOLD}

Oh well, can't be the star athlete

all the time. Good work Ken.

ARNOLD shakes hands with KEN.

LUCY

They should be back by now .

Everyone else is.

TERRY comes bursting onto the malae.

TERRY

Marcus here?

LUCY

What? He's with you isn't he?

TERRY

I left him to have a rest

LUCY

You what?

TERRY

He was slowing us down so I//

LUCY

//he's still in the bush? What's wrong with you Terry! He'll get lost! Shit! 


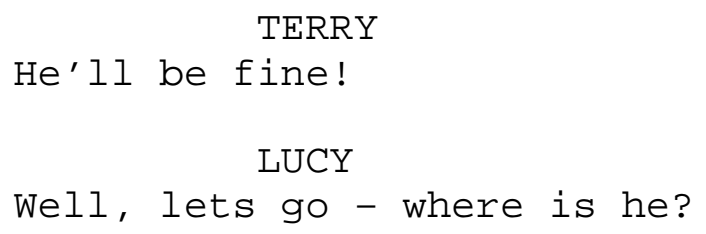

LUCY pulls at TERRY and drags him back towards the plantation.

89 EXT. LEFAGA VILLAGE ROAD - AFTERNOON

LAGI and EPELU and ORLANDO watch as LAFAELE tries to winch the container out of the ditch with a digger. The operation is not going well.

\section{LAGI}

No, not that way. That way, that way! Keep going, no, you've lost it.

ARNOLD jogs up to the group.

$$
\begin{aligned}
& \text { ARNOLD } \\
& \text { Marcus' is lost. }
\end{aligned}
$$

90 INT. TUI'S FALE - AFTERNOON

LINE is quietly putting photo albums back into the wooden chest in the corner of the fale.

MELESINA sleeps on the fala with a mosquito net over her. TUI is feeding chickens with coconut scrapings.

ORLANDO jogs up the path.

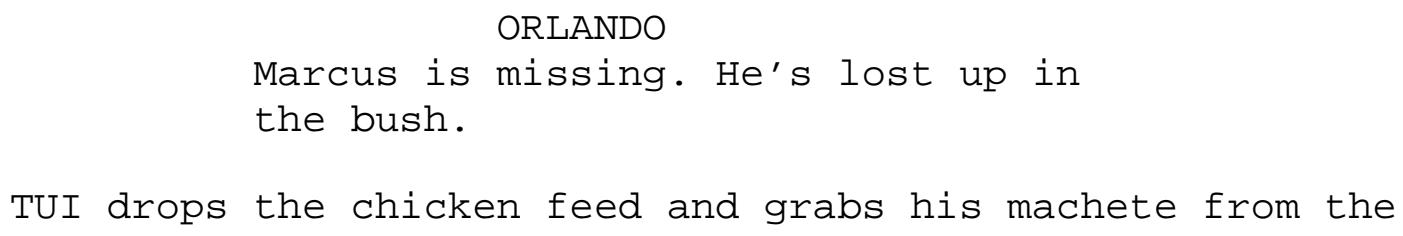


91 EXT. TAFILI PLANTATION - AFTERNOON

It is late in the afternoon. LUCY and TERRY are wading through the bush. TERRY is bare-chested.

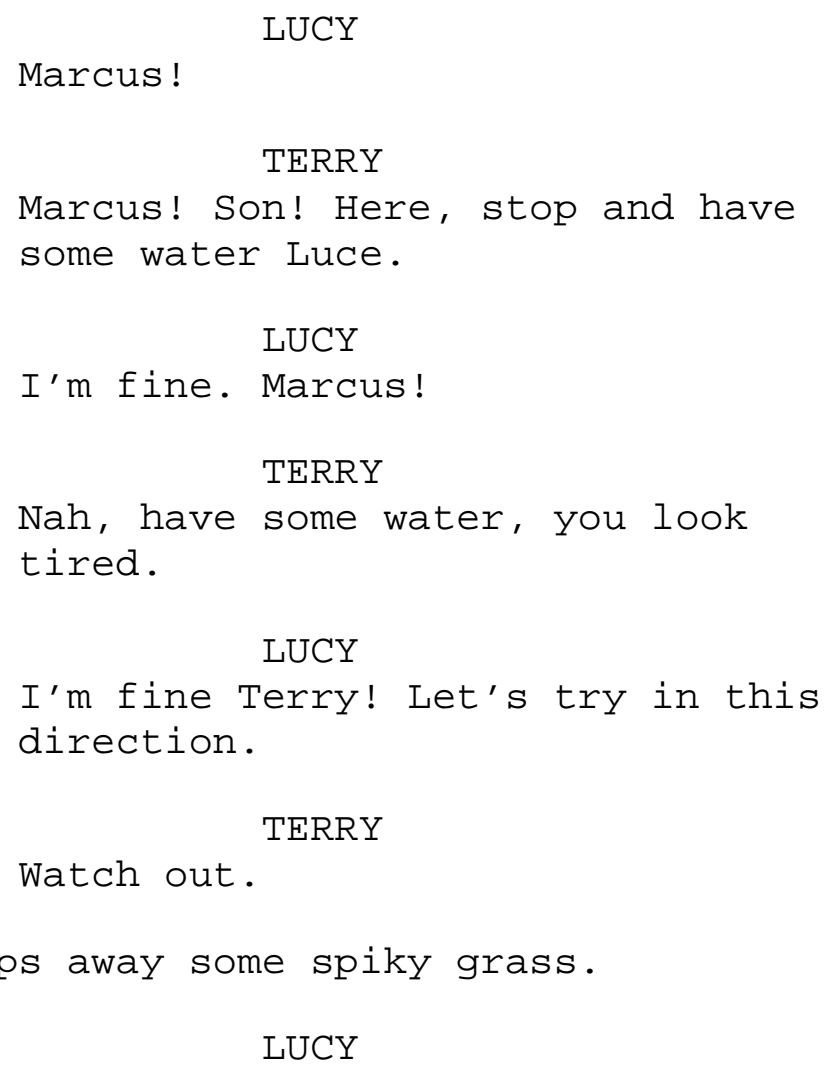

LUCY

Did you hear that? 
LUCY and TERRY separate awkwardly and LUCY strides off into the distance after the noise.

92 EXT. THE BONE HOUSE, TAFILI PLANTATION - DUSK

MARCUS, exhausted, reaches out from the bush to the edge of a small and abandoned fale.

MARCUS tumbles inside, flops down on the ground and closes his eyes.

A withered hand reaches out to MARCUS and pats his brow and places a red ula fale over his neck.

Many pairs of legs wade through high grass. Hands hold torches and the lights flick through the bush. The sound of 'Marcus' rings out across the bush.

94 EXT. LEFAGA VILLAGE MALAE - DUSK

LAGI wrings her hands as she oversees the search parties, making sure that everyone has supplies, torches etc.

EPELU watches her as he talks to two burly Samoan police officers that are taking notes on a clipboard.

A TV Samoa news crew drive up the road, park their news van by the container and begin to unload their camera and sound gear.

LAGI collapses. EPELU rushes over to her.

95 INT. TUI'S FALE - NIGHT

LAGI wakes up staring at the fale rafters.

LAGI

Marcus! Have they found him?

LAGI sits up. LINE is massaging her ankle. 


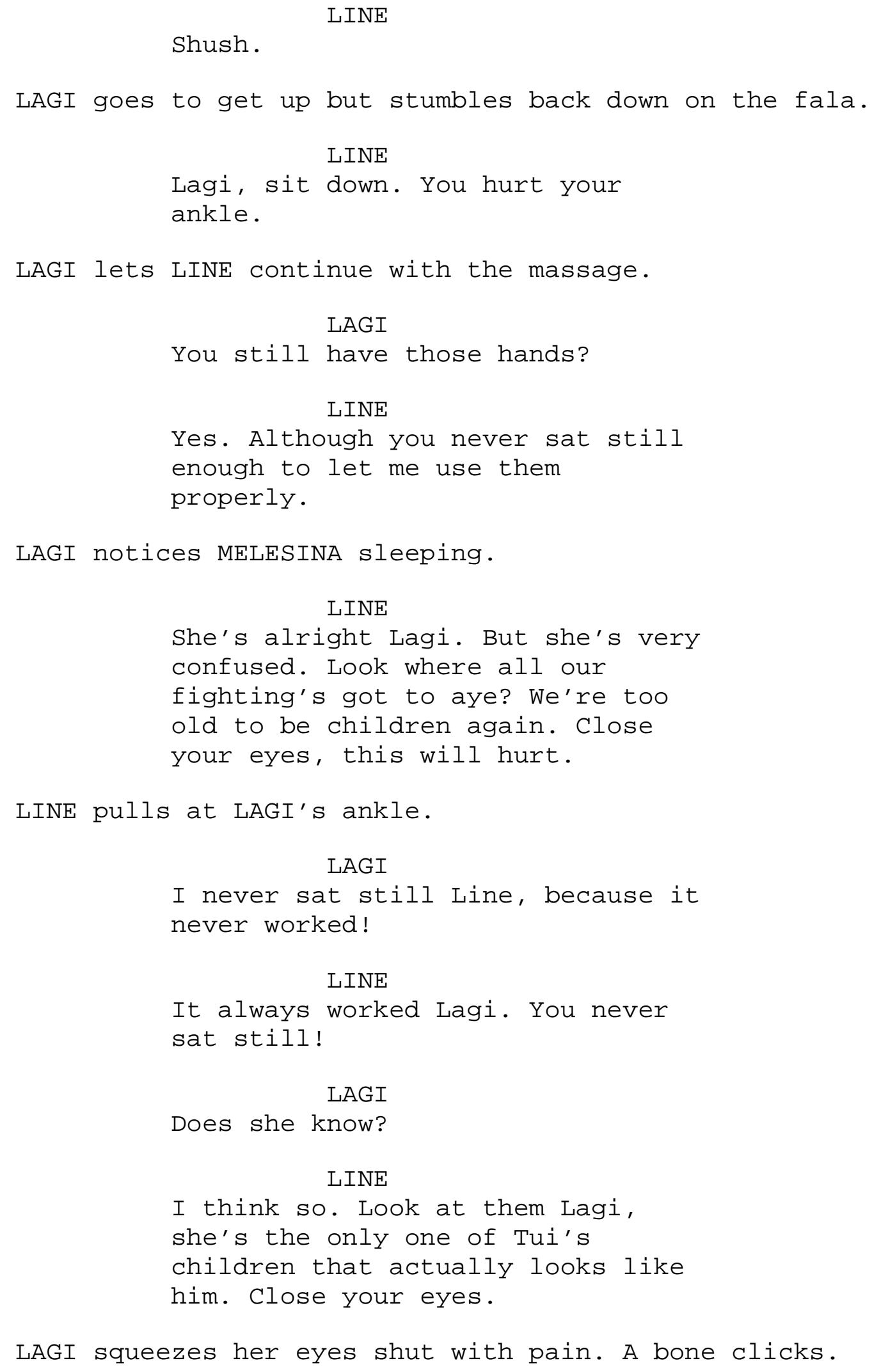

LAGI squeezes her eyes shut with pain. A bone clicks. 
96 EXT. FALE' $A^{\prime} S E^{\prime} E^{\prime} L A B E A C H ~-~ D A Y$

MARCUS wakes to the sound of gentle thudding. He opens his eyes and sees TEUILA (17) pounding a huge pestle and mortar filled with cocoa beans.

MARCUS smiles at TEUILA then sniffs the air. He has no shirt on and a clean lava lava.

MARCUS looks out at the white sandy beach and turquoise water just beyond the fale.

MARCUS looks to see TEUILA studying him. She returns to grinding the beans.

MARCUS

How did I get here?

TEUILA

I thought you'd tell me. I came

back from swimming and I found you

sleeping in my fale. (beat) Koko?

TEUILA stands up and MARCUS sees, for the first time, her heavily pregnant belly.

\section{MARCUS \\ Is this real?}

TEUILA throws a t-shirt at MARCUS. MARCUS quickly puts this on.

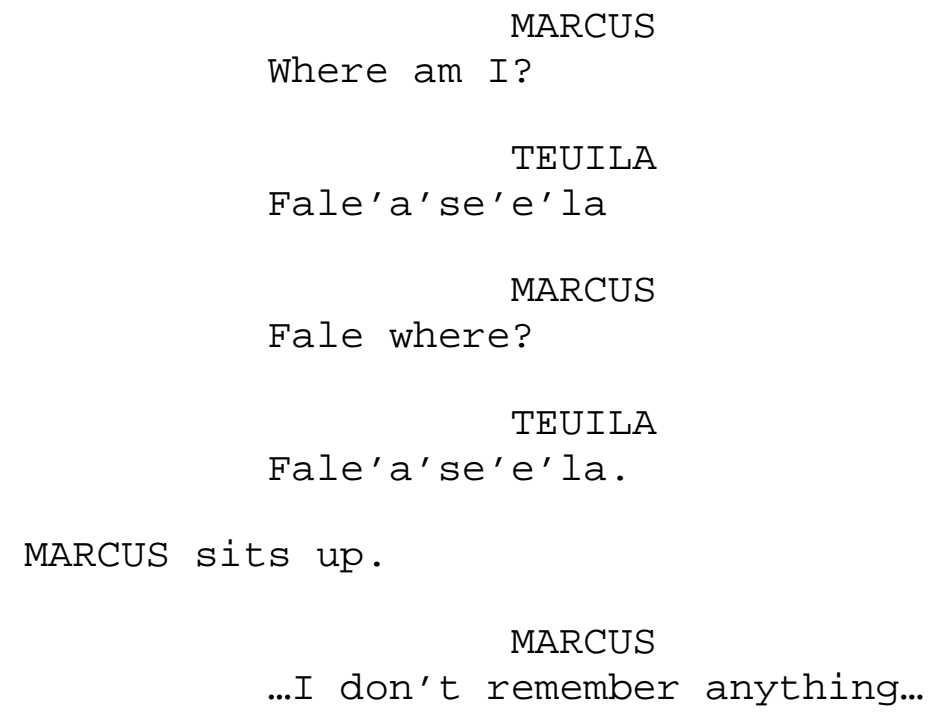


TEUILA

What about your name?

MARCUS

Marcus.

TEUILA

I'm Teuila. (beat) Stop staring at my stomach Marcus.

MARCUS

Sorry. I didn't mean to...

TEUILA

You're from New Zealand?

MARCUS

Yeah. Here for a family reunion. Shit!!!! They'll be wondering where I am!

TEUILA

Which family?

MARCUS

Tafili?

TEUILA

Oh. You know Orlando Tafili?

MARCUS

Yeah. Dad's cousin or something

MARCUS signals to a man combing the beach. The man spots the fale and its occupants and starts jogging over.

TEUILA

My brother. I told him you were

the baby's father.

What?

MARCUS

MARCUS starts shuffling himself along the fale floor trying to hide behind a post.

TEUILA laughs and for the first time, smiles. 
TEUILA

Just kidding. I don't know who it

is. I'm here on my own.

Really?

MARCUS

TEUILA pats her belly.

TEUILA

Yes.

The man is now at the fale. It is ARNOLD who peeps his head inside.

ARNOLD

Marcus! Where you been? Your Mum's

scared to death! You okay son?

MARCUS

Yeah.

MARCUS

Yeah.

97 EXT. LEFAGA VILLAGE ROAD - DAY

A purple paisley velvet coffin with chrome handles lies in the back of a white hearse that is slowly making its way down Lefaga village main road. Following the hearse is a police officer riding a motorbike, Samoan 'CHIPS' style. Following the motorbike is a white beaten up taxi.

\section{CUT TO:}

98 EXT. LEFAGA METHODIST CHURCH - DAY

The whole village, wearing white, waits on the steps of the Lefaga Methodist Church.

The purple coffin is carried somberly into the church and then a second fuchsia velvet coffin is carried in behind it.

We pan out to see The Boys standing outside looking across from the malae. 
NIKI

Can't believe the old man had it in him!

TALAVOU

It's always the quiet ones, aye

Asema?

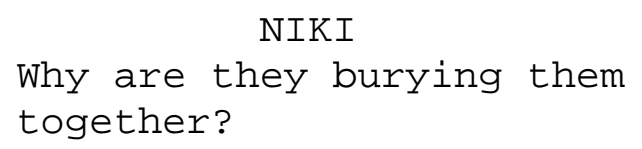

NIKI

Why are they burying them

together?

ASEMA

Denial. They want to remember him

for the man he was. But now we

know that he was nothing but a callous murderer.

TALAVOU and NIKI turn to look at ASEMA, surprised.

NIKI

That's very dramatic Asema!

ASEMA

Sorry, Niki. I know he was one of our best clients.

TALAVOU

You know, his wife Fuatino used to

have it off with one of the woman

from town.

\section{NIKI}

What's this? The prodigal son

returns.

ARNOLD, MARCUS and TEUILA walk across the malae.

LUCY and TERRY are huddled talking with police.

MARCUS

Mum!

LUCY spins around and runs over. TERRY follows her. Big hugs for MARCUS.

ORLANDO joins the group to hug MARCUS, notices the ula fale around his neck. 


\section{ORLANDO}

Where'd you get this Marcus?

MARCUS

Dunno. Woke up with it.

ORLANDO's face clouds over. He masks this with a grimace and splits away noticing TEUILA.

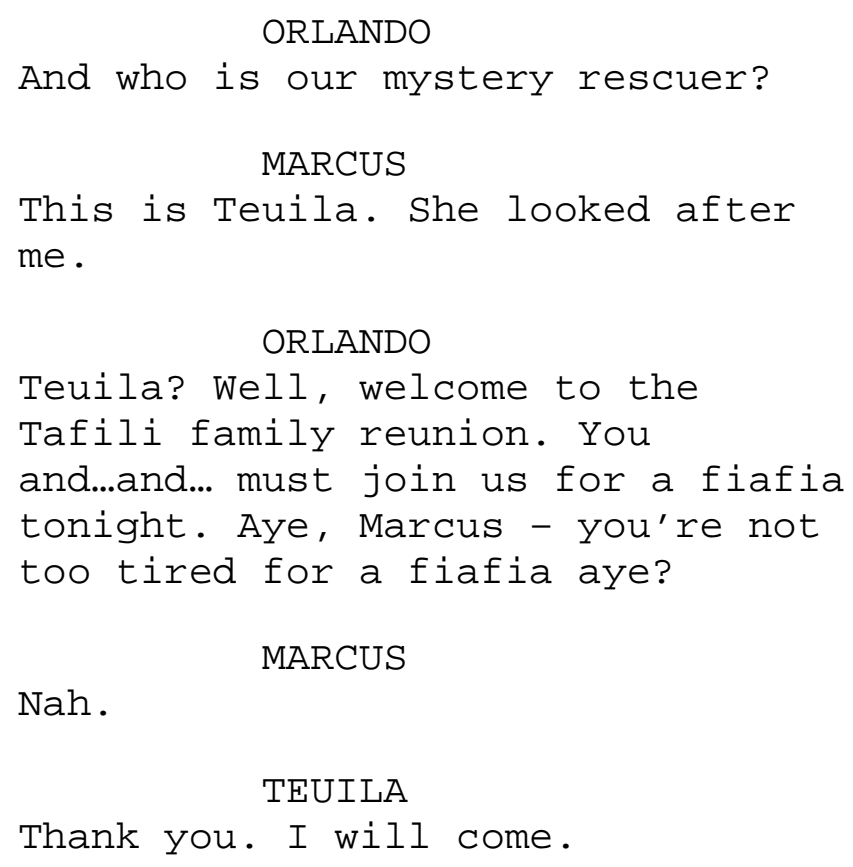


LAGI and LINE both look bemused.

100 INT. TAFILI COOKING FALE - DAY

ORLANDO is whacking a machete through a huge ta'amu (yam) that is as big as his leg.

LAFAELE is scraping coconut into a wooden bowl.

ORLANDO

How did he get it?

LAFAELE

Maybe Tusitala gave it to him on

the first day?

ORLANDO

Bullshit! And why him?

LAFAELE

I don't know. Just happy it's not me...

ORLANDO

Things always work out for you don't they Lafaele? You fat, lazy talking chimpanzee!

LAFAELE

Maybe that's why Tusitala chose Marcus for the title instead of any of us Orlando? Maybe he's more deserving, he's a good boy Orlando.

ORLANDO

So what...who cares about a crazy old man's wishes anyway...I'm still the boss around here...

101 INT. LEFAGA METHODIST CHURCH HALL - AFTERNOON

LINE and LAGI are flitting about in the hall checking decorations and table arrangements for the mafutaga fiafia. The twins are ordering around teams of young girls who are sitting on the stage to get to work. 


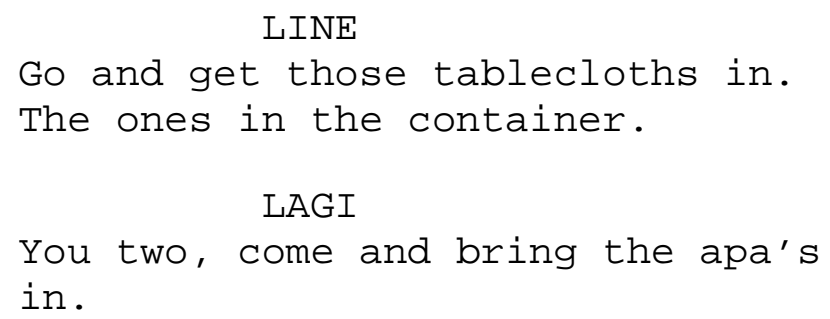

\section{EXT. TAFILI FALE PALAGI - AFTERNOON}

It is now raining heavily. The doors of the freight container swing open as the wind howls through the village.

A young man wrestles with the doors trying to shut them.

\section{INT. LEFAGA METHODIST CHURCH HALL - NIGHT}

A pair of legs are flapping to the beat of the up-tempo siva song 'Ao ma le Po' that is being played by the band on stage. People, old and young alike are dancing hard on the dance floor.

ORLANDO is in the band on stage playing bass guitar. LAFAELE plays drums.

SAANE sits talking with LUCY and MARCUS. 
MELESINA and LAGI both rest their legs on chairs in front of them.

TEUILA sits close to Marcus, grasping her stripy bag tightly.

TERRY is dancing with a pair of women who are trying to outdance each other.

ARNOLD side-dances with an elderly obese woman.

TUI sits with some old men at the back of the hall.

ORLANDO abruptly stops drumming and moves towards the microphone with his eye trained on the ula fale around MARCUS's neck.

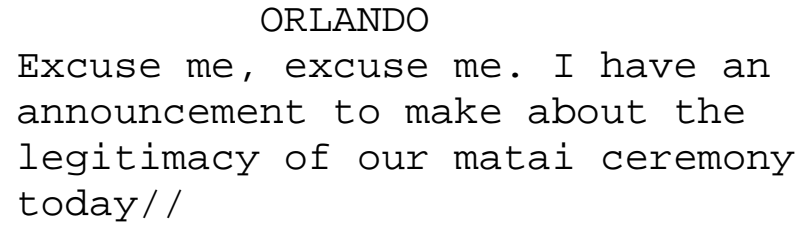

LAFAELE cottons on to what ORLANDO is up to. He is vainly trying to find the right cord to pull to cut the power to the microphone.

ORLANDO is interrupted, not by LAFAELE, but by a low moan that resonates through the hall. It comes from TEUILA. She drops her stripy bag on the floor and breathes heavily.

Everyone has now swiveled around to focus on TEUILA.

LAFAELE is still madly trying to cut wires. He pulls a cord, sparks go flying and the hall is enveloped instantly in darkness.

TEUILA lets out another low moan. There is a crash of drums on the stage. LAFAELE falls over.

Lightning from the night sky lights up the hall for a few seconds.

105 INT. LEFAGA METHODIST CHURCH HALL - NIGHT

A lighter flame lights up TEUILA's face. It is held by LINE. LAGI is guiding TEUILA to the door. 
106 INT. TAFILI FALE PALAGI - NIGHT

TEUILA squats over a chair supported by LINE and LUCY. LAGI reaches down between TEUILA's legs.

\section{LAGI}

Baby's head's coming. Big push

girl, big push!

TEUILA strains, her face distorting with pain. She cries out long and hard.

LAGI catches a pink newborn baby in her arms and quickly wraps it up in a towel. The baby cries strongly.

LINE cuts the umbilical cord. LAGI hands the baby to LINE.

LAGI

Healthy boy! Let's get this

placenta out now. Ready to turn

her?

107 EXT. TAFILI COOKING FALE - NIGHT

LAGI and LINE sit at the table drinking Koko Samoa. Lightning flashes in the sky.

$$
\begin{gathered}
\text { LINE } \\
\text { We used to make a good team }
\end{gathered}
$$

LAGI

Hhhhmmm. That young girl's going

to have it hard.

LAFAELE wanders past the fale. LAGI calls out to him.

$$
\text { LAGI }
$$

Hey! Better tell Orlando he's a grandfather!

\section{LAFAELE}

A grandfather? 
108 INT. LEFAGA METHODIST CHURCH HALL - NIGHT

The band has gone acoustic and are singing traditional Samoan songs to the gentle strumming of guitars. The hall is candle lit.

ORLANDO is conversing with a table of older men - the matai's. He points at SAANE who are sitting at the opposite end of the hall.

LAFAELE walks up to ORLANDO and whispers in his ear.

ORLANDO has a stunned expression on his face. He backs away from the matai, pardoning himself and vanishes out of the hall.

MARCUS hops up to the stage and fiddles around with some cords. He pulls his cell phone out of his pocket and plugs into the PA.

MARCUS turns the cell phone on and pushes buttons. A Justin Timberlake track blasts out of the speakers.

The young people in the hall cheer and move back to the dancefloor.

\section{EXT. LEFAGA LAGOON - NIGHT}

TUI is paddling in his canoe across the lagoon. He takes a break to wipe the sweat from his face and drink water.

TUI paddles a few more metres and stops. He has reached the edge of the lagoon, the reef.

TUI sits on the pale blue lagoon side and contemplates the dark waters beyond the reef.

He flits his hand across the water. TUI feels something. He reaches over and pulls up a handful of brown worms.

TUI laughs and laughs and howls at the moon. 
The whale shark swims beside TUI as he paddles back towards the village.

CUT TO:

MONTAGE :

H) Legs rush into the lagoon to get a hold of the Palolo

I) Tafili's fan out and munch on Palolo straight out of the sea

J) Young children scoop the brown worms into buckets, bowls.

K) MELESINA floats on her back amongst the melee with her pregnant bump sticking out of the water laughing.

110 EXT. LEFAGA VILLAGE MALAE - MORNING

"Final day"

MARCUS, LUCY, ARNOLD, TEUILA and MELESINA are sitting under a tree watching a vigorous volley-ball game on the malae. MARCUS relaxes back on a faded deckchair.

TERRY walks over to them across the malae. He wears a white shirt and a black I'e faitaga (formal lavalava). TERRY sits down next to MARCUS.

TERRY

Hey son .

MARCUS

Dad.

ARNOLD opens his mouth to say something. LUCY pinches him on the thigh.

How you feeling? 


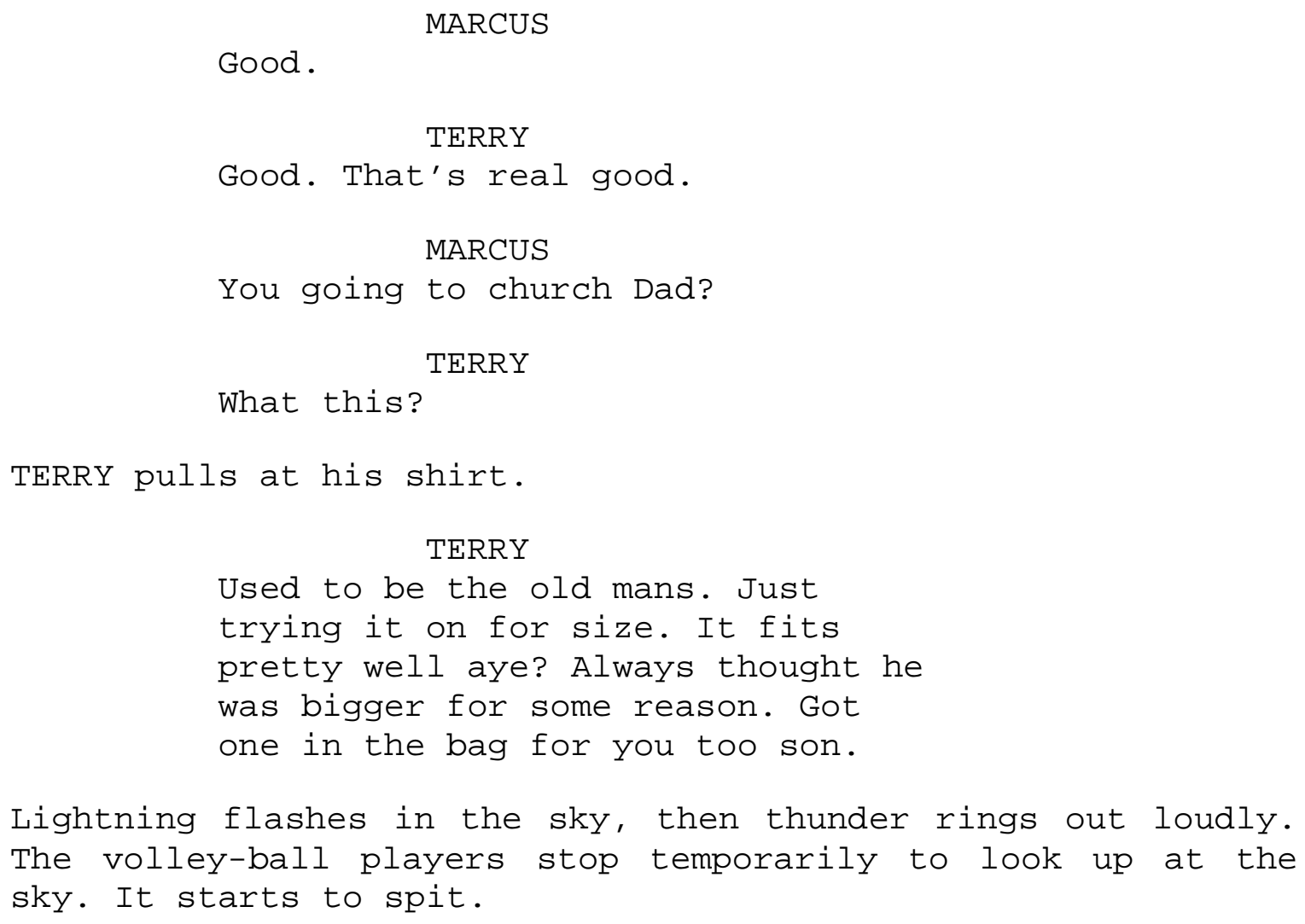

\section{EXT. LEFAGA LAGOON - NIGHT}

The whale shark glides back into the lagoon and sound from the fiafia carries across the water.

\section{EXT. LEFAGA VILLAGE - MORNING}

Chickens scratch in the dirt for food. A thin blanket of smoke from the Sunday umu's rises above the village.

MARCUS, TERRY and ARNOLD are all shaving at the water pipe next to the cooking fale. They alternate in rinsing their respective razors.

TERRY and ARNOLD try to rinse at the same time. ARNOLD lets TERRY go first.

MELESINA and LUCY are lying next to each other chatting on their mattresses in the fale palagi. 
TUI and EPELU are sorting through a chest full of old photos in TUI's fale.

LAFAELE is supervising ORLANDO scraping coconut at the back of the cooking fale.

113 INT. TAFILI FALE PALAGI - MORNING

An outstretched hand from under a sheet. LAGI lies with her eyes closed, smile on her face. Cut to black screen.

THE END 